\title{
Acanthoceras and Urosolenia species (Diatomeae) in subtropical reservoirs from South Brazil: Ultrastructure, distribution and autoecology
}

\author{
Priscila Izabel Tremarin ${ }^{1,2}$, Eduardo Gomes Freire ${ }^{I}$, Vanessa Majewski Algarte ${ }^{I}$ \& Thelma Veiga Ludwig ${ }^{I}$ \\ ${ }^{1}$ Departamento de Botânica, Universidade Federal do Paraná, Curitiba, PR, Brazil. \\ ${ }^{2}$ Corresponding author: Priscila Izabel Tremarin, e-mail: ptremarin@gmail.com
}

TREMARIN, P.I., FREIRE, E.G., ALGARTE, V.M., LUDWIG, T. Acanthoceras and Urosolenia species (Diatomeae) in subtropical reservoirs from South Brazil: Ultrastructure, distribution and autoecology. Biota Neotropica. 15(1): e20140043. http://dx.doi.org/10.1590/1676-06032014004314

\begin{abstract}
Acanthoceras Honigmann and Urosolenia Round \& Crawford emend. Rott, Kling \& McGregor species were studied based on samples of 19 hydroelectric power plants reservoirs located in the State of Paraná, Southern Brazil. Autoecological informations of Urosolenia species complement the study. One Acanthoceras and four Urosolenia species were identified: A. zachariasii (Brun) Simonsen, U. amazonica Sala, Núñez-Avellaneda \& Vouilloud, U. eriensis var. morsa (West \& G.S.West) Bukhtiyarova, $U$. longiseta Zacharias and $U$. obesa Freire, Tremarin \& Ludwig. Morphological variation of frustules was described and illustrated by optical and scanning electron microscopy, and compared with similar species such as $U$. delicatissima Sala, Núñez-Avellaneda \& Vouilloud and U. eriensis var. eriensis (H.L.Smith) Round \& Crawford. The pioneer record of $U$. amazonica to Brazil and unprecedent details of the ultrastructure of $A$. zachariasii and $U$. longiseta are included in this study. Cellular densities differed among evaluated reservoirs showing strong correlations with inorganic nitrogen concentrations, N/P ratio and temperature. The results suggested higher densities in periods of warmer temperatures and low availability of the nitrogen compounds and confirmed that species respond strongly to local environmental gradients.
\end{abstract}

Keywords: centric diatom, lentic environments, State of Paraná, taxonomy.

TREMARIN, P.I., FREIRE, E.G., ALGARTE, V.M., LUDWIG, T. Espécies de Acanthoceras e Urosolenia (Diatomeae) em reservatórios subtropicais do sul do Brasil: ultraestrutura, distribuição e autoecologia. Biota Neotropica. 15(1): e20140043. http://dx.doi.org/10.1590/1676-06032014004314

Resumo: Espécies de Acanthoceras Honigmann e Urosolenia Round \& Crawford emend. Rott, Kling \& McGregor foram estudadas com base em amostras provenientes de 19 reservatórios de usinas hidrelétricas do estado do Paraná, sul do Brasil. Informações sobre a autoecologia das espécies de Urosolenia complementam o estudo. Uma espécie de Acanthoceras e quatro de Urosolenia foram identificadas: A. zachariasii (Brun) Simonsen, U. amazonica Sala, Núñez-Avellaneda \& Vouilloud, $U$. eriensis var. morsa (West \& G.S.West) Bukhtiyarova, U. longiseta Zacharias e U. obesa Freire, Tremarin \& Ludwig. A variação morfológica das frústulas foi descrita e ilustrada através de microscopia óptica e eletrônica de varredura e comparada com a de espécies similares, como U. delicatissima Sala, NúñezAvellaneda \& Vouilloud e U. eriensis var. eriensis (H.L.Smith) Round \& Crawford. O registro pioneiro de $U$. amazonica para o Brasil e detalhes inéditos da ultraestrutura de A. zachariasii e U. longiseta estão contemplados neste estudo. As densidades celulares diferiram entre os reservatórios avaliados e mostraram forte correlação com concentrações de nitrogênio inorgânico, relação N/P e temperatura. Os resultados sugeriram densidades mais elevadas em períodos de temperaturas mais quentes e baixa disponibilidade de compostos nitrogenados e confirmaram que as espécies respondem fortemente aos gradientes ambientais locais.

Palavras-chave: ambientes lênticos, diatomácea cêntrica, estado do Paraná, taxonomia.

\section{Introduction}

Acanthoceras Honigmann and Urosolenia Round \& Crawford emend. Rott, Kling \& McGregor are centric diatoms worldwide distributed, occurring primarily in plankton of lentic environments (Rott et al. 2006). These genera are mainly characterized by having open girdle bands, cylindrical or subcylindrical frustules, conical to semi-conical valves ornamented or not, calyptra and the presence or not of the seta (Round et al. 1990, Rott et al. 2006). The valves of Acanthoceras presents two calyptra while Urosolenia have only one (Round et al. 1990).

Detailed research on Acanthoceras and Urosolenia taxa is difficult to realize due to weakly silicified frustules, which are often destroyed by the usual techniques of cleaning and preservation. This fact may be the reason of so scarce records of these genera. Scanning and transmission electron microscopies 
have been useful and often essential to distinguish among species, since they enable the visualization of structures indistinguishable in optical microscopy (Morales 2005). Accordingly, identifications of some species performed only with light microscopy should be reviewed (Rott et al. 2006).

Recent studies on Acanthoceras and Urosolenia were developed by Rott et al. (2006), Sala et al. (2008), Li et al. (2009), Karthick \& Kociołek (2011) and Tremarin et al. (2013), with descriptions of eight new species and some new combinations.

Brazilian surveys have found Acanthoceras zachariasii (Brun) Simonsen and five taxa of Urosolenia: U. brauni (Hustedt ) Rott \& Kling, U. longiseta (Zacharias) Edlund \& Stoermer, $U$. eriensis (H.L.Smith) Round \& Crawford var. eriensis, U. eriensis var. morsa (West \& G.S West) Bukhtiyarova and $U$. obesa Freire, Tremarin \& Ludwig (Torgan et al. 1999, Rott et al. 2006, Melo et al. 2004, Raupp et al. 2009, Tremarin et al. 2009, Silva et al. 2011, Eskinazi-Leça et al. 2012, Tremarin et al. 2013). Informations about the ultrastructure of Urosolenia species found in Brazil are not routinely added to the studies, except for Torgan \& Becker (1998) who described the morphology of $U$. eriensis var. morsa, and Tremarin et al. (2013) when proposed $U$. obesa.

According to Reynolds et al. (2002), Urosolenia are included within functional A-group (centric diatoms) characterized by preferring lakes with clear and often well-mixed water, tolerating nutrients deficiency. Representatives of the genus were detected in shallow Amazonian high-waters stages. In Brazilian subtropical reservoirs, Urosolenia species occurred in winter mixed waters (Silva et al. 2005). Ramberg (1987) found $A$. zachariasii and $U$. eriensis during stratification of water column, both disappearing in the mixing period. Edlund
\& Stoermer (1993) remark that Acanthoceras is largely distributed and may be found in alcalin, shallow and eutrophic lakes and rivers from Norh America. Urosolenia may occur in highly diverse habitats and in oligotrophic to eutrophic conditions.

Thus, this study aimed to describe the morphology and expand the geographic distribution of Acanthoceras and Urosolenia species that occurred in plankton from hydropower plants reservoirs in the State of Paraná, Southern Brazil. Also, we identified the environmental factors closer correlated with Urosolenia species densities.

\section{Material and methods}

For the taxonomic analysis, samplings were carried out quarterly at 19 hydroelectric power plants reservoirs from the State of Paraná, Southern Brazil (Figure 1, Table 1), over four consecutive years (2007-2010), at subsurface $(\approx 30 \mathrm{~cm}$ depth) and at the limit of the photic zone. A total of 768 phytoplanktonic samples were collected with a van Dorn sampler and were preserved with Lugol's iodine acetic solution (1\%) (Bicudo \& Menezes 2006). The material was washed with distilled water to prepare permanent slides mounted with $\operatorname{Naphrax}^{\circledR}$ (R.I. $\left.=1.74\right)$. The specimens found were measured and photographed under Olympus BX40 light microscopy (LM) equipped with Olympus DP71 image capture, using phase contrast (1000x). Some of the material was dried on aluminum stubs and covered with gold and studied using a JEOL JSM 6360LV scanning electron microscopy (SEM), operated at 15 $\mathrm{kV}$ and $8 \mathrm{~mm}$ working distance, at the Electron Microscopy Center of the Universidade Federal do Paraná. Analyzed

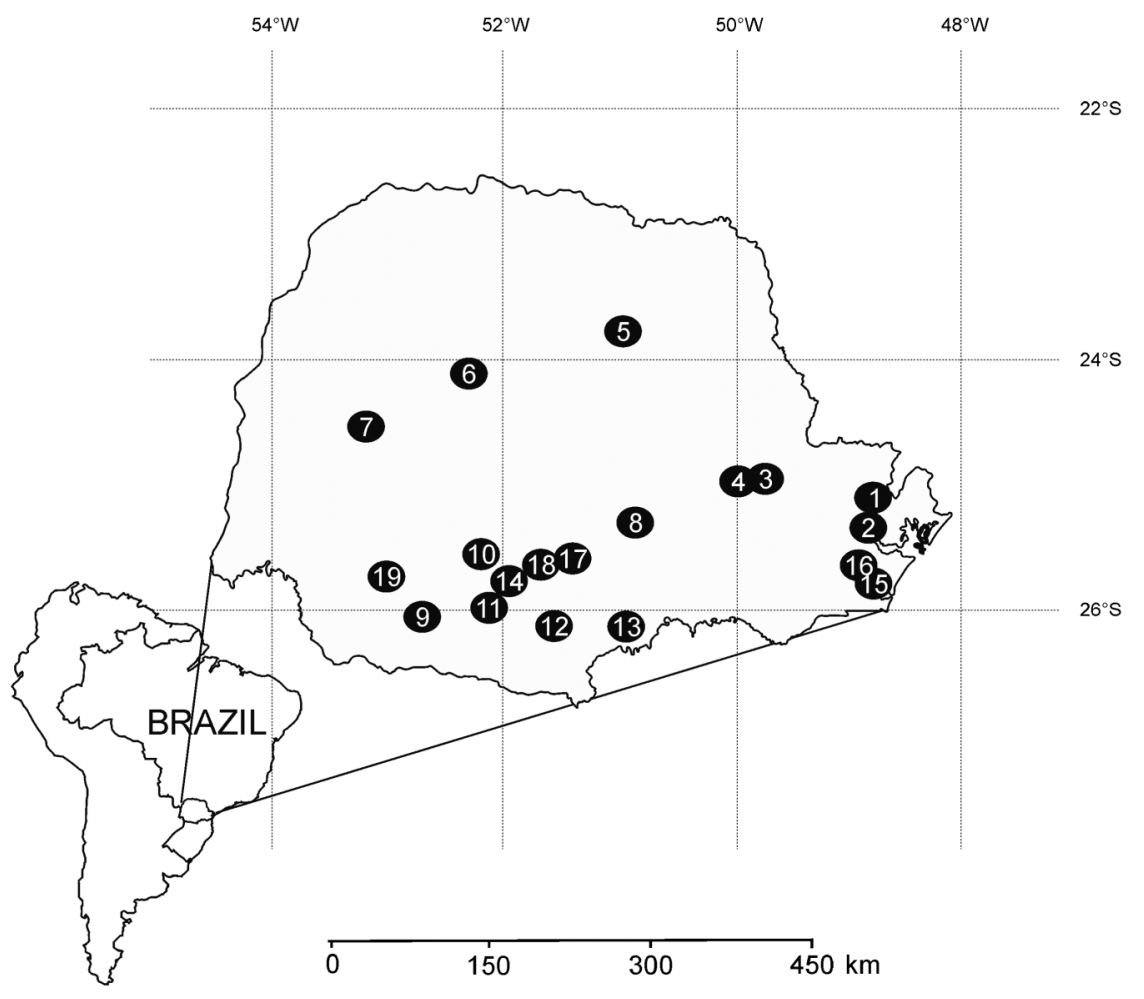

Figure 1. Sampling locations in the State of Paraná, Brazil. Hydroelectric power plants reservoirs: 01- Capivari, 02- Marumbi, 03- São Jorge, 04Pitangui, 05- Apucaraninha, 06- Mourão, 07- Melissa, 08- Rio dos Patos, 09- Chopim, 10- Cavernoso, 11- Segredo, 12- Foz do Areia, 13- Salto do Vau, 14- Jordão, 15- Chaminé, 16- Guaricana, 17- Fundão, 18- Santa Clara, 19- Salto Caxias. 
Table 1. Data of the sampling sites in the State of Paraná and register number in the herbarium of Universidade Federal do Paraná (UPCB).

\begin{tabular}{|c|c|c|c|c|}
\hline Reservoir & Station & UPCB/Date & Municipality & Geographic coordinates \\
\hline Apucaraninha & E2 & $\begin{array}{l}\text { 69524-2007; 60508-2008; 68842-2009; } \\
68866-2010\end{array}$ & Tamarana & $23^{\circ} 44^{\prime} 56^{\prime \prime} \mathrm{S} / 50^{\circ} 56^{\prime} 33^{\prime \prime} \mathrm{W}$ \\
\hline Capivari & $\mathrm{E} 2$ & $\begin{array}{l}\text { 59525-2007; 60509-2008; 68843-2009; } \\
68867-2010\end{array}$ & Antonina & $24^{\circ} 59^{\prime} 10^{\prime \prime} \mathrm{S} / 48^{\circ} 47^{\prime} 20^{\prime \prime} \mathrm{W}$ \\
\hline Cavernoso & E2 & $\begin{array}{l}\text { 59526-2007; 60510-2008; 68844-2009; } \\
\text { 68868-2010 }\end{array}$ & Virmond & $25^{\circ} 23^{\prime} 49^{\prime \prime} \mathrm{S} / 52^{\circ} 11^{\prime} 24^{\prime \prime} \mathrm{W}$ \\
\hline \multirow[t]{2}{*}{ Chaminé } & E2 & $\begin{array}{l}\text { 59527-2007; 60511-2008; 68845-2009; } \\
68869-2010\end{array}$ & São José dos Pinhais & $25^{\circ} 41^{\prime} 36^{\prime \prime} \mathrm{S} / 49^{\circ} 01^{\prime} 14^{\prime \prime} \mathrm{W}$ \\
\hline & E4 & $\begin{array}{l}\text { 59528-2007; 60512-2008; 68846-2009; } \\
\text { 68870-2010 }\end{array}$ & & \\
\hline Chopim & $\mathrm{E} 2$ & $\begin{array}{l}\text { 59529-2007; 60513-2008; 68847-2009; } \\
68871-2010\end{array}$ & Itapejara d'Oeste & $25^{\circ} 53^{\prime} 26^{\prime \prime} \mathrm{S} / 52^{\circ} 43^{\prime} 05^{\prime \prime} \mathrm{W}$ \\
\hline \multirow[t]{3}{*}{ Foz do Areia } & $\mathrm{E} 2$ & $\begin{array}{l}\text { 59530-2007; 60514-2008; 68848-2009; } \\
68872-2010\end{array}$ & Pinhão & $26^{\circ} 03^{\prime} 39^{\prime \prime} \mathrm{S} / 51^{\circ} 30^{\prime} 09^{\prime \prime} \mathrm{W}$ \\
\hline & E3 & $\begin{array}{l}\text { 59531-2007; 60515-2008; 68849-2009; } \\
\text { 68873-2010 }\end{array}$ & & \\
\hline & E5 & $\begin{array}{l}\text { 59532-2007; 60516-2008; 68850-2009; } \\
68874-2010\end{array}$ & & \\
\hline Fundão & E3 & 65977-2008; 68864-2009; 68888-2010 & Candói & $25^{\circ} 32^{\prime} 04^{\prime \prime} \mathrm{S} / 51^{\circ} 48^{\prime} 55^{\prime \prime} \mathrm{W}$ \\
\hline Guaricana & E2 & $\begin{array}{l}\text { 59533-2007; 60517-2008; 68851-2009; } \\
\text { 68875-2010 }\end{array}$ & Guaratuba & $25^{\circ} 42^{\prime} 31^{\prime \prime} \mathrm{S} / 48^{\circ} 58^{\prime} 18^{\prime \prime} \mathrm{W}$ \\
\hline Jordão & $\mathrm{E} 2$ & $\begin{array}{l}\text { 59534-2007; 60518-2008; 68852-2009; } \\
68876-2010\end{array}$ & Reserva do Iguaçu & $25^{\circ} 45^{\prime} 14^{\prime \prime} \mathrm{S} / 52^{\circ} 04^{\prime} 54^{\prime \prime} \mathrm{W}$ \\
\hline Marumbi & E2 & 68865-2009; 68889-2010 & Morretes & $25^{\circ} 25^{\prime} 35^{\prime \prime} \mathrm{S} / 48^{\circ} 55^{\prime} 44^{\prime \prime} \mathrm{W}$ \\
\hline Melissa & E2 & $\begin{array}{l}\text { 59535-2007; 60519-2008; 68853-2009; } \\
\text { 68877-2010 }\end{array}$ & Corbélia & $24^{\circ} 32^{\prime} 12^{\prime \prime} \mathrm{S} / 53^{\circ} 12^{\prime} 28^{\prime \prime} \mathrm{W}$ \\
\hline Mourão & E2 & $\begin{array}{l}\text { 59536-2007; 60520-2008; 68854-2009; } \\
68878-2010\end{array}$ & Campo Mourão & $24^{\circ} 06^{\prime} 20^{\prime \prime} \mathrm{S} / 52^{\circ} 19^{\prime} 42^{\prime \prime} \mathrm{W}$ \\
\hline Pitangui & E2 & $\begin{array}{l}\text { 59537-2007; 60521-2008; 68855-2009; } \\
\text { 68879-2010 }\end{array}$ & Ponta Grossa & $25^{\circ} 01^{\prime} 41^{\prime \prime} \mathrm{S} / 50^{\circ} 06^{\prime} 06^{\prime \prime} \mathrm{W}$ \\
\hline Rio dos Patos & $\mathrm{E} 2$ & $\begin{array}{l}\text { 59538-2007; 60522-2008; 68856-2009; } \\
68880-2010\end{array}$ & Prudentópolis & $25^{\circ} 10^{\prime} 37^{\prime \prime} \mathrm{S} / 50^{\circ} 56^{\prime} 29^{\prime \prime} \mathrm{W}$ \\
\hline \multirow[t]{2}{*}{ Salto Caxias } & E3 & $\begin{array}{l}\text { 59539-2007; 60523-2008; 68857-2009; } \\
68881-2010\end{array}$ & $\begin{array}{l}\text { Capitão Leônidas } \\
\text { Marques }\end{array}$ & $25^{\circ} 32^{\prime} 43^{\prime \prime} \mathrm{S} / 53^{\circ} 06^{\prime} 05^{\prime \prime} \mathrm{W}$ \\
\hline & E5 & $\begin{array}{l}\text { 59540-2007; 60524-2008; 68858-2009; } \\
\text { 68882-2010 }\end{array}$ & & \\
\hline Salto do Vau & E2 & $\begin{array}{l}\text { 59541-2007; 60525-2008; 68859-2009; } \\
68883-2010\end{array}$ & União da Vitória & $25^{\circ} 58^{\prime} 50^{\prime \prime} \mathrm{S} / 51^{\circ} 43^{\prime} 14^{\prime \prime} \mathrm{W}$ \\
\hline Santa Clara & E3 & 65976-2008; 68863-2009; 68887-2010 & Candói & $25^{\circ} 39^{\prime} 14^{\prime \prime} \mathrm{S} / 51^{\circ} 54^{\prime} 26^{\prime \prime} \mathrm{W}$ \\
\hline São Jorge & E2 & $\begin{array}{l}\text { 59542-2007; 60526-2008; 68860-2009; } \\
\text { 68884-2010 }\end{array}$ & Ponta Grossa & $24^{\circ} 59^{\prime} 45^{\prime \prime} \mathrm{S} / 49^{\circ} 59^{\prime} 39^{\prime \prime} \mathrm{W}$ \\
\hline \multirow[t]{2}{*}{ Segredo } & E2 & $\begin{array}{l}\text { 59543-2007; 60527-2008; 68861-2009; } \\
68885-2010\end{array}$ & Mangueirinha & $26^{\circ} 00^{\prime} 47^{\prime \prime} \mathrm{S} / 51^{\circ} 52^{\prime} 43^{\prime \prime} \mathrm{W}$ \\
\hline & E3 & $\begin{array}{l}\text { 59544-2007; 60528-2008; 68862-2009; } \\
68886-2010\end{array}$ & & \\
\hline
\end{tabular}

Source: Ribeiro et al. (2006).

samples (2007-2010) were stored in the Herbarium of the Universidade Federal do Paraná (UPCB). The terminology used in the description of species was based on Round et al. (1990) and Rott et al. (2006).

For the quantitative and ecological analysis, samplings were carried out quarterly over six consecutive years (2007-2012). Urosolenia quantification was performed in Ütermohl' chambers (1958) under Olympus IX70 inverted microscope at a magnification of $600 \mathrm{x}$, enumerated in random fields (Uhelinger 1964) and followed the stabilization curve of the number of species. Sedimentation time of the samples was carried out according to Lund et al. (1958). The physical and chemical analyses (Table 2) were performed by the technical staff of the Instituto de Tecnologia para o Desenvolvimento (LACTEC) following the Standard Methods (APHA 1989).

Environmental data were summarized by a principal component analysis (PCA, Legendre \& Legendre 1998) with $\log$ transformed and standardized variables. The selection of the axes for the interpretation of the results followed the Broken Stick criteria (Jackson 1993). Spearman rank correlation coefficients were used to measure the degree of association between the densities of Urosolenia amazonica, U. longiseta and 


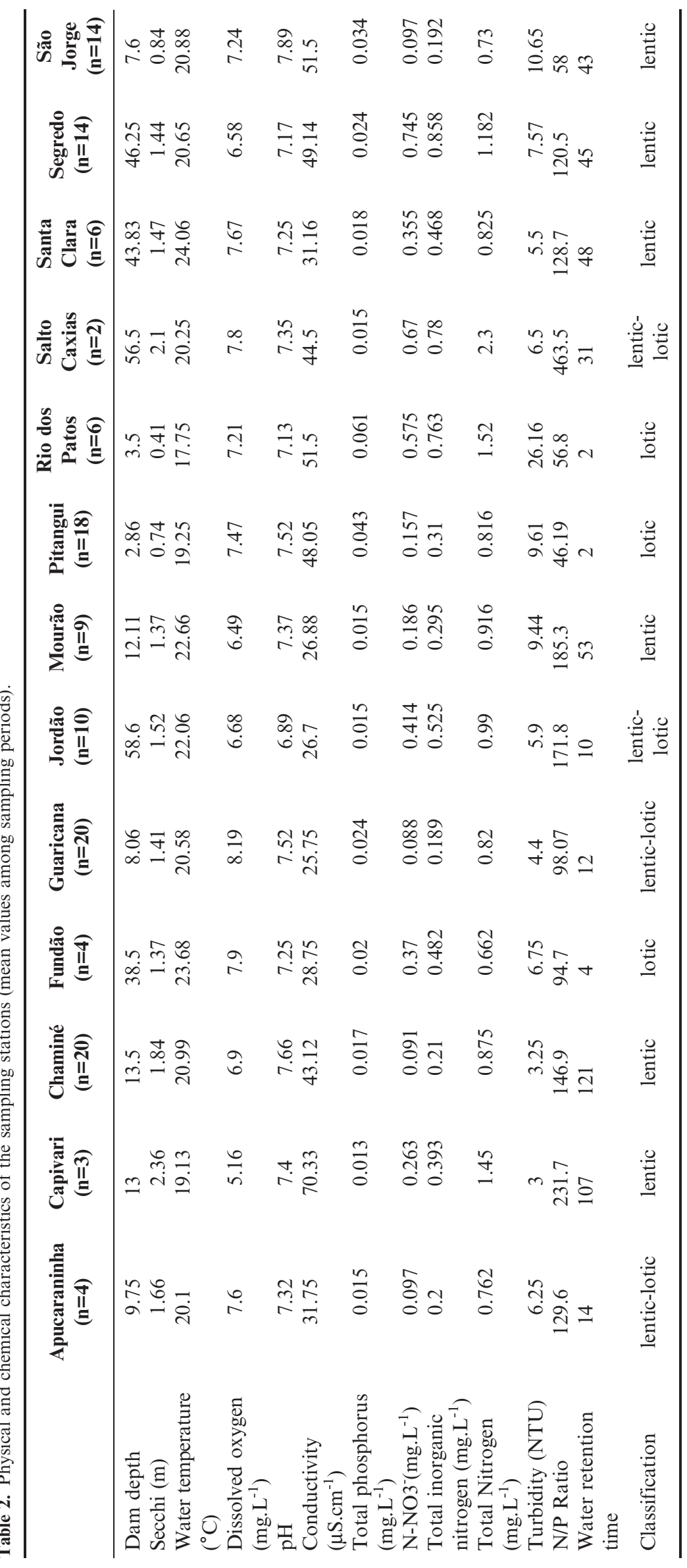




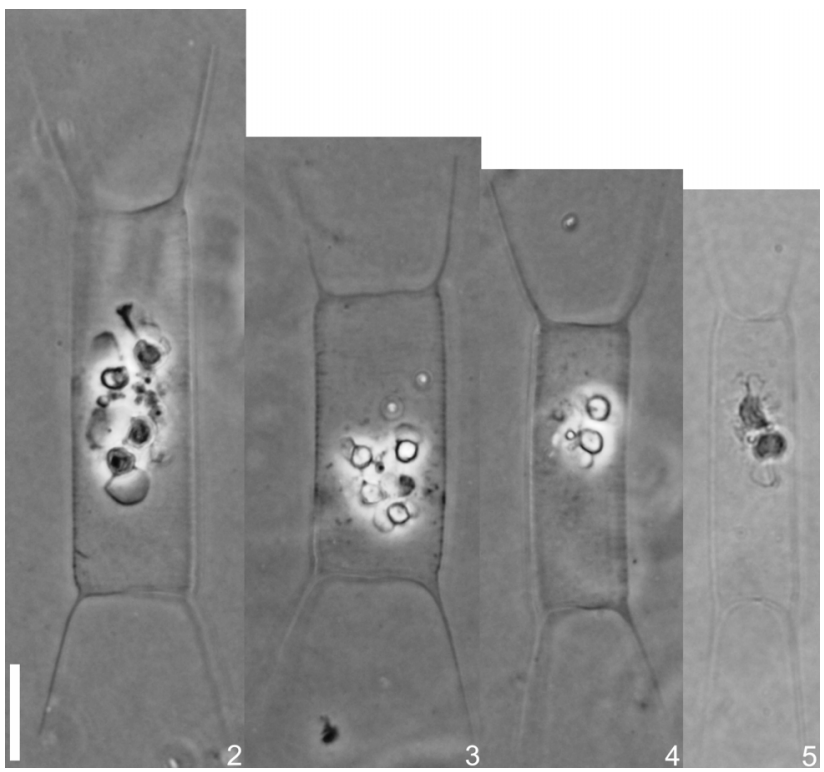

Figures 2-5. Acanthoceras zachariasii. LM. Scale: $10 \mu \mathrm{m}$.

$U$. obesa and abiotic variables. The relationship between the environmental variables and the density of three species of Urosolenia was evaluated by means of stepwise multiple regression analysis. The method consists of starting with a single predictor variable and then adding variables one at a time until the addition of further variables does not produce an appreciable increase in the coefficient of determination (Sokal \& Rohlf 1981). Except for $\mathrm{pH}$, other variables were logtransformed. Data distribution and multicollinearity among the abiotic factors were checked before performing the analysis (Zar 2010). The principal component analysis (PCA), Spearman correlations and multiple regressions were carried out respectively using PC-ORD (McCune \& Mefford 1999) and STATISTICA (StatSoft 2005).

The autoecology of Urosolenia species was performed with the taxa that present densities $>3$ cells. $\mathrm{mL}^{-1}$ in the quantitative analysis ( $U$. amazonica, U. longiseta and $U$. obesa) and only with reservoirs that have had regular sampling of physical and chemical data.

\section{Results and discussion}

Five taxa were identified in the qualitative analysis: $A$. zachariasii, $U$. amazonica, $U$. eriensis var. morsa, U. longiseta and $U$. obesa. The taxa occurred in 15 of the 19 reservoirs (except for Cavernoso, Chopim, Marumbi and Melissa reservoirs). Specimens of Acanthoceras and Urosolenia were registered in $12 \%$ of analyzed samples, being Urosolenia amazonica present in $87 \%$ of these samples, followed by $U$. obesa $(80 \%)$, U. longiseta $(60 \%)$, U. eriensis var. morsa $(16 \%)$ and $A$. zachariasii $(10 \%)$.

Acanthoceras zachariasii (Brun) Simonsen, Bacillaria 2: 55, 1979.

Basionym: Attheya zachariasii Brun, Forschungsberichte aus der Biologischen Station zu Plön 2: 53, pl. 1, fig. 11, 1894.

Synonyms: Acanthoceras magdeburgense Honigmann, Archiv für Hydrobiologie und Planktonkunde 5: 77, pl. 2, fig. a, 1910 .
Acanthoceras magdeburgense var. lata Honigmann, Archiv für Hydrobiologie und Planktonkunde 5: 78, pl. 2, fig. b, 1910.

Rhizosolenia eriensis var. zachariasii (Brun) Playfair, Proceedings of the Linnean Society of New South Wales 37(3): p. 538; pl. 56, fig. 33-35, 1913.

Frustules solitary, subcylindrical, straight, 56.5-73.4 $\mu \mathrm{m}$ total long, 6.1-13.5 $\mu \mathrm{m}$ width (Figures 2-5). Valve face straight with conical apices, ornamented with round to irregular areolae, 50-55 in $10 \mu \mathrm{m}$, arranged in rows and extending onto the calyptra base (Figures 6,7). Valve mantle edge surrounded by a thin hyaline margin (Figure 7). Calyptra straight, positioned in the valve apices, 14.9-17.8 $\mu \mathrm{m}$ long, positioned at right to strongly oblique angle with the pervalvar axis. Tip of spine-like extension with four small teeth (Figures 9-11). Terminal seta not observed. Cingulum with several semicircular open and narrow bands, 9-14 in $10 \mu \mathrm{m}$, perforated by round poroids, ca. 7 in $1 \mu \mathrm{m}$ (Figure 8). Bands of the median region of frustule perforated by a few poroids, scarcely distributed. Coarser rounded pores, varying in size and number, present on the girdle bands (Figure 8). Two to four discoid to plate-like chloroplasts per cell (Figures 2-5).

The genus Acanthoceras was proposed by Honigmann (1910) when describing $A$. magdeburgense Honigmann, a later synonym of Attheya zachariasii Brun. The name Acanthoceras had already been proposed by Kützing (1842) for a red alga genus currently considered a later homonym of Ceramium Roth (Edlund \& Wynne 1996). Since the name Acanthoceras Kützing was not in use and that Acanthoceras Honigmann was reported for a diatom, Edlund \& Wynne (1996) suggested the conservation of the name Acanthoceras that was recommended by the Committee for Algae (see Compère 1999).

Although the ultrastructure of Acanthoceras zachariasii has been illustrated and described by Round et al. (1990) and the morphology of its resting spores analyzed by Edlund \& Stoermer (1993), some taxonomically important details on the frustule morphology of this species remained unknown. The number of calyptra teeth and density of poroids in the girdle bands are recorded for the first time in this study.

The specimens of Acanthoceras zachariasii from Brazilian reservoirs showed smaller individuals than the type material of the species, but they were similar to other studied specimens, with intermediate sizes, as can be seen on Table 3. The Brazilian material has smaller calyptra length and higher number of girdle bands when compared with materials analyzed by HuberPestalozzi (1942), Rivera (1974), Shirata \& Valente-Moreira (1987) and Ferrario et al. (1992) (Table 3). There are few records of the metric variation of A. zachariasii. Rivera (1974) remarked that the number of bands is not a constant feature in A. zachariasii, so we believe that the specimens analyzed in our study represent an extreme of the population and would not justify the proposition of a new taxon. Anyway, it is necessary to analyze the type material of A. zachariasii, especially in SEM, to study the fine ornamentation of the frustules (ex. calyptra teeth, details of the valve, calyptra and bands), for comparison among different populations. However, we advise on this difficult task, given the frequent and fast disappearing of Acanthoceras individuals in the stored samples. The low silicified frustules of Acanthoceras, as well as Urosolenia, do not resist long time in chemical preserved samples (Tremarin et al. 2013). 


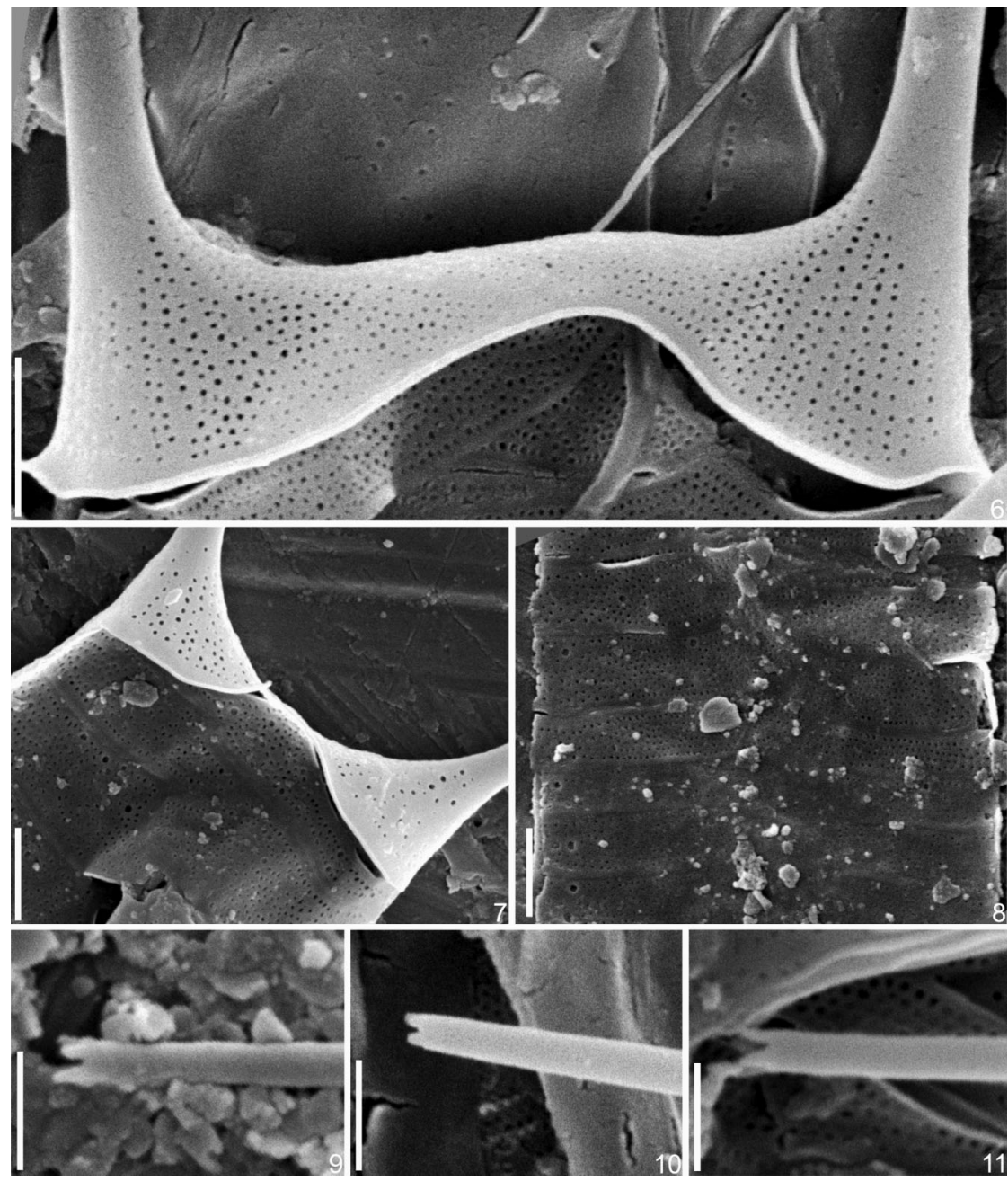

Figures 6-11. Acanthoceras zachariasii. SEM. Figs 6-7. Valve surface. Scales: $2 \mu \mathrm{m}$. Fig. 8. Girdle bands in the median region of frustule. Scale: 2 $\mu \mathrm{m}$. Figs 9-11. Teeth of the calyptra. Scales: $1 \mu \mathrm{m}$.

Table 3. Morphometric features of Acanthoceras zachariasii var. zachariasii and A. zachariasii var. curvata.

\begin{tabular}{|c|c|c|c|c|c|c|c|}
\hline \multirow[b]{2}{*}{ Reference } & \multicolumn{6}{|c|}{ A. zachariasii var. zachariasii } & \multirow{2}{*}{$\begin{array}{c}\begin{array}{c}\text { A. zachariasii } \\
\text { var. curvata }\end{array} \\
\text { Rivera } \\
\text { (1974) }\end{array}$} \\
\hline & this study & Brun (1874) & $\begin{array}{l}\text { Huber- } \\
\text { Pestalozzi } \\
\text { (1942) }\end{array}$ & $\begin{array}{l}\text { Rivera } \\
(1974)\end{array}$ & $\begin{array}{c}\text { Shirata \& } \\
\text { Valente- } \\
\text { Moreira } \\
(1987)\end{array}$ & $\begin{array}{c}\text { Ferrario } \\
\text { et al. (1992) }\end{array}$ & \\
\hline $\begin{array}{l}\text { Total frustule length } \\
(\mu \mathrm{m})\end{array}$ & $56.5-73.4$ & $\ldots$ & $12-100$ & $\ldots$ & $\cdots$ & $\ldots$ & $\ldots$ \\
\hline Frustule length $(\mu \mathrm{m})$ & $29.1-39.7$ & $60-100$ & $\ldots$ & $42-86$ & $31-45.6$ & $20-36$ & 43-90 \\
\hline Frustule width $(\mu \mathrm{m})$ & $6.1-13.5$ & $15-20$ & $15-25$ & $8.5-17$ & $9.7-18.1$ & $11-12$ & $8-11$ \\
\hline $\begin{array}{l}\text { Calyptra length } \\
(\mu \mathrm{m})\end{array}$ & $14.9-17.8$ & $\ldots$ & $40-70$ & $24-32$ & $18.6-30.1$ & $20-25$ & $20-30$ \\
\hline $\begin{array}{l}\text { Girdle bands (in } 10 \\
\mu \mathrm{m} \text { ) }\end{array}$ & $9-14$ & $\ldots$ & $3.4-4$ & $4-6$ & $\ldots$ & $4-4.5$ & $4.5-5$ \\
\hline $\begin{array}{l}\text { Porous of the bands } \\
\text { (in } 1 \mu \mathrm{m} \text { ) }\end{array}$ & 7 & $\ldots$ & $\ldots$ & $\ldots$ & $\ldots$ & $\ldots$ & $\ldots$ \\
\hline Teeth of the calyptra & 4 & $\ldots$ & $\ldots$ & $\ldots$ & $\ldots$ & $\ldots$ & $\ldots$ \\
\hline Country & Brazil & Germany & $\begin{array}{l}\text { Switzerland } \\
\text { and Germany }\end{array}$ & Chile & Brazil & Argentina & Chile \\
\hline
\end{tabular}


The species has only one variety, Acanthoceras zachariasii var. curvata Rivera, proposed by Rivera (1974) based on the frustule curvature in relation to the pervalvar axis.

Acanthoceras zachariasii is a freshwater taxon, worldwide distributed, recorded to Germany, Australia, Switzerland, Sweden, Finland, Russia, United States, Chile, Argentina and Brazil (Brun 1874, Hustedt 1930, Cleve-Euler 1951, Rivera 1974, Shirata \& Valente-Moreira 1987, Ferrario et al. 1992, Edlund \& Stoermer 1993, Medvedeva et al. 2009).

Occurrence in samples (UPCB) - São Jorge reservoir 68884; Pitangui reservoir 68879.

Urosolenia amazonica Sala, Núñez-Avellaneda \& Vouilloud, Diatom Research 23(1): 164, pl. 1, figs 1-9, 2008.
Frustules solitary or in pairs, cylindrical, straight, 78-194 $\mu \mathrm{m}$ total long, 7.2-12.8 $\mu \mathrm{m}$ width (Figures 12-19). Valve face conical, 2.4-5.4 length, ornamented with rounded areolae 7-9 in $1 \mu \mathrm{m}$, randomly arranged and extending onto the calyptra base (Figures 20-22). Valve mantle edge surrounded by a thin hyaline margin (Figures 21, 22). Calyptra straight and eccentric, 24.8$38.2 \mu \mathrm{m}$ long, positioned at right to slightly oblique angle with the pervalvar axis. Tip of spine-like extension with 4-6 small teeth (Figures 23-26). Terminal seta not observed. Cingulum with several semi-circular open and narrow bands, 8-11 in 10 $\mu \mathrm{m}$, perforated by round poroids, ca. $7-10$ in $1 \mu \mathrm{m}$ (Figure 27). Valvocopula wider than the other bands, with poroids irregularly distributed and serrated margin (Figures 20, 22).

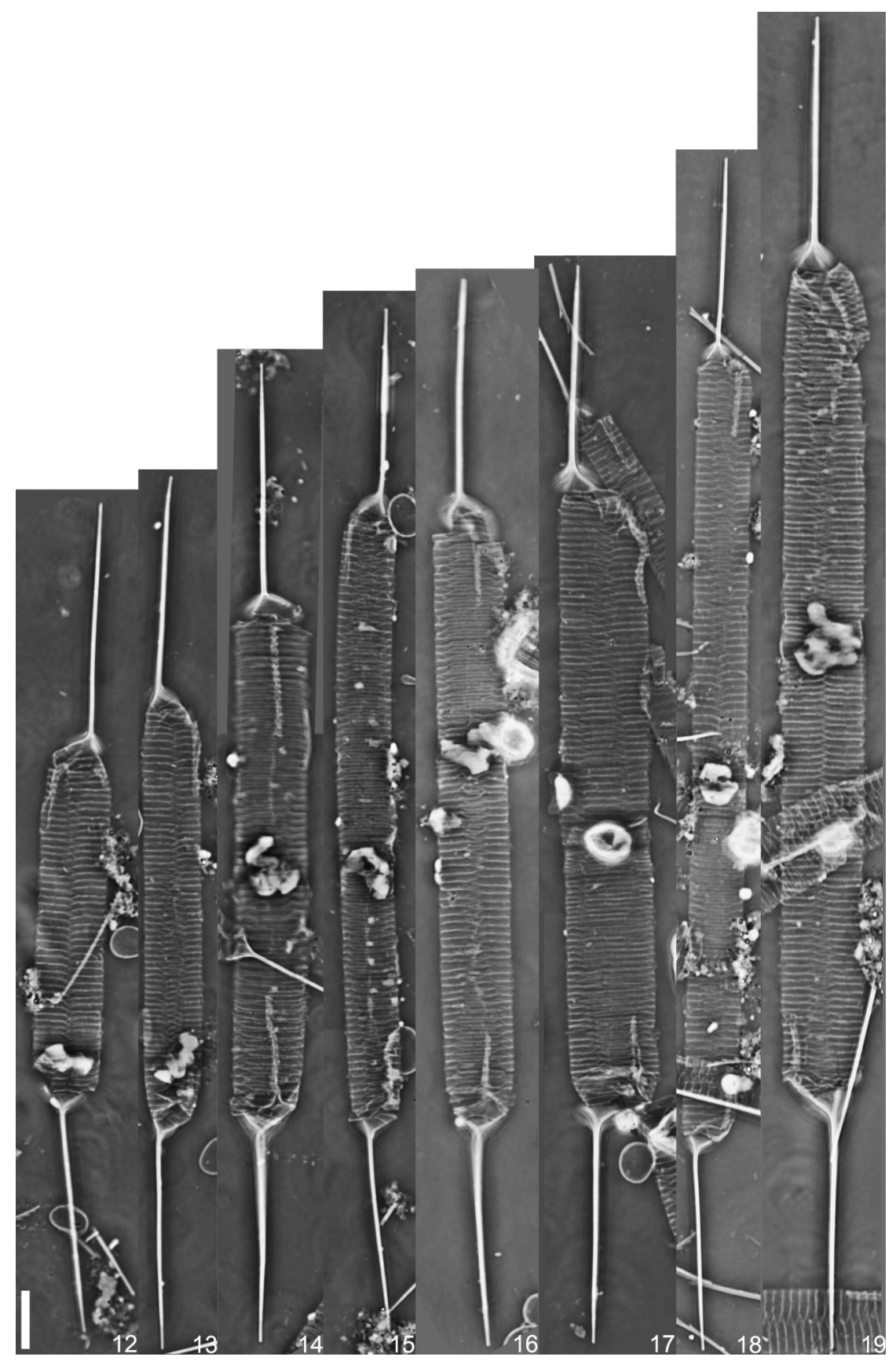

Figures 12-19. Urosolenia amazonica, LM. Scale: $10 \mu \mathrm{m}$. 


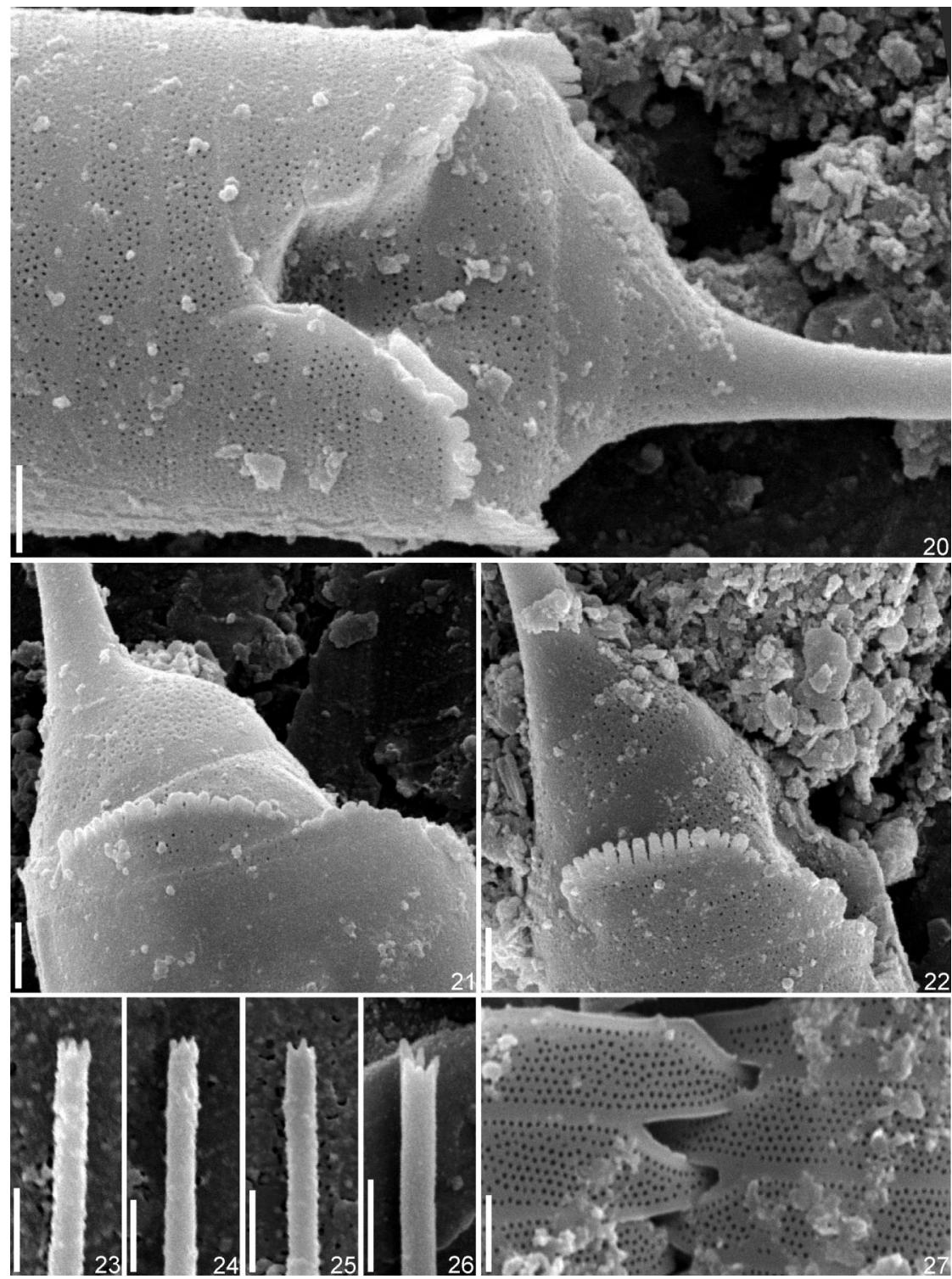

Figures 20-27. Urosolenia amazonica, SEM, external view. Fig. 20. Aspect of valve and the insertion site of the calyptra of adjacent cell. Scale: $1 \mu \mathrm{m}$. Figs 21,22 . Overview of valve. Note the serrated valvocopulae. Scales: $1 \mu \mathrm{m}$. Figs 23-26. Detail of calyptra teeth. Scales: $1 \mu \mathrm{m}$. Fig. 27. Detail of girdle bands showing the poroids and imbrication line in the median region of frustule. Scale: $1 \mu \mathrm{m}$.

Urosolenia amazonica is similar to U. eriensis var. eriensis, mainly by the dimensions and shape of frustules, but differs by higher number of girdle bands and valvocopula with serrate margin (Table 4) (Huber-Pestalozzi 1942, Krammer \& LangeBertalot 1991, Sala et al. 2008). The absence of more detailed features of $U$. eriensis var. eriensis, as number of calyptra teeth, calyptra length and density of poroids in the bands, difficult a more precise comparison between the two species.

Urosolenia eriensis var. morsa is very similar to $U$. amazonica in light microscopy. However, the former may have larger valves and valvocopulae with smooth edge (HuberPestalozzi 1942, Krammer \& Lange-Bertalot 1991, Torgan \& Becker 1998). Furthermore, Urosolenia eriensis var. morsa have three teeth in the calyptra as documented by Torgan \& Becker (1998) (Table 4). We believe that some Brazilian exemplars recorded as $U$. eriensis var. morsa in previous studies may be $U$. amazonica, due to the similarities between the species in light microscopy.
We found some exemplars of $U$. amazonica with longer total length of frustule and smaller valve length than that reported by Sala et al. (2008) (Table 4), but the valvocopulae serrate and calyptra teeth were always present in the observed specimens.

Urosolenia amazonica was proposed based on material from the Colombian and Peruvian Amazon (Sala et al. 2008), with no subsequent records. Thus, this is the first citation of the species in Brazil.

Occurrence in samples (UPCB) - Apucaraninha reservoir 59524, 60508, 68842; Guaricana reservoir 59533, 60517, 68875, 68875; São Jorge reservoir 59542, 60526, 68860, 68884; Pitangui reservoir 59537, 60521, 68855, 68879; Fundão reservoir 68864, 68888; Foz do Areia reservoir 60515, 60516, 60517, 68872, 68874; Santa Clara reservoir 68863, 68887; Jordão reservoir 59520, 68852, 68876; Segredo reservoir 59543, 59544, 60527, 60528, 68861, 68862, 68885, 68886; Salto Caxias reservoir 68857, 68858, 68881, 68882; Mourão reservoir 59536, 60520, 
Acanthoceras and Urosolenia species in the Brazil

Table 4. Morphometric and morphological variation of Urosolenia amazonica and related taxa.

\begin{tabular}{|c|c|c|c|c|c|c|}
\hline \multirow[b]{2}{*}{ Reference } & \multicolumn{2}{|c|}{ U. amazonica } & \multicolumn{2}{|c|}{$U$. erienses var. eriensis } & \multicolumn{2}{|c|}{ U. eriensis var. morsa } \\
\hline & this study & $\begin{array}{l}\text { Sala et al. } \\
\quad(2008)\end{array}$ & $\begin{array}{c}\text { Krammer \& } \\
\text { Lange- Bertalot } \\
\text { (1991) }\end{array}$ & $\begin{array}{l}\text { Huber- } \\
\text { Pestalozzi } \\
(1942)\end{array}$ & $\begin{array}{c}\text { Huber-Pestalozzi } \\
\text { (1942), Krammer } \\
\text { \& Lange-Bertalot } \\
\text { (1991) }\end{array}$ & $\begin{array}{c}\text { Torgan \& } \\
\text { Becker } \\
(1998)\end{array}$ \\
\hline Total frustule length $(\mu \mathrm{m})$ & $78-194$ & $76-120$ & $40-150$ & $40-150$ & $80-135^{*}$ & $\ldots$ \\
\hline Frustule width $(\mu \mathrm{m})$ & $7.2-12.8$ & $6-18$ & $6-15$ & $6-15$ & $5-20$ & $6.0-12.0$ \\
\hline Frustule length $(\mu \mathrm{m})$ & $32.8-118.8$ & $\cdots$ & $\cdots$ & $\ldots$ & $40-68$ & $40-84$ \\
\hline Girdle bands (in $10 \mu \mathrm{m}$ ) & $8-11$ & $8-16$ & $3-4$ & $3-4$ & $6-9$ & $5-10(12)$ \\
\hline Porous in the bands (in $1 \mu \mathrm{m}$ ) & $7-10$ & $7-14$ & $\cdots$ & $\cdots$ & $\ldots$ & $7-9$ \\
\hline Calyptra length $(\mu \mathrm{m})$ & $24.8-38.2$ & $27-48$ & $\ldots$ & $28-38$ & $22-36$ & $22-45$ \\
\hline Valve length $(\mu \mathrm{m})$ & $2.4-5.4$ & $3-9.5$ & $\ldots$ & $2-15$ & $5-20$ & $6-12$ \\
\hline Teeth in the calyptra & $4-6$ & $4-6$ & $\ldots$ & $\ldots$ & $\ldots$ & $2+$ ligula* \\
\hline Valvocopula & serrate & serrate & $\ldots$ & $\ldots$ & $\ldots$ & smooth* \\
\hline
\end{tabular}

* data measured or observed in the illustrations.

68854; Chaminé reservoir 59527, 59528, 60511, 60512, 68845, 68846, 68869, 68870; Rio dos Patos reservoir 68856, 68880.

Urosolenia eriensis var. morsa (West \& G. S. West) Bukhtiyarova, Algologia 5(4): 417, 1995.

Basionym: Rhizosolenia eriensis var. morsa W. \& G. S. West, Transactions of the Royal Society of Edinburgh 41(3): 509, pl. 6, fig. 23, 1905.

Synonyms: Rhizosolenia morsa (W. \& G. S. West) W. \& G.S. West, Transactions of the Royal Irish Academy 33: 109, pl. 11, fig. 5, 1906.

Urosolenia eriensis var. morsa (W. West \& G. S. West) Torgan in Torgan \& Becker, Iheringia, Série Botânica 50: 90; figs 2-9, 1998.

Frustules solitary or in pairs, cylindrical, straight, 73.1$143.4 \mu \mathrm{m}$ total long, 6.9-20.3 $\mu \mathrm{m}$ width (Figures 28-31). Valve face conical, 3.8-7.6 length, ornamented with rounded areolae $7-10$ in $1 \mu \mathrm{m}$, randomly arranged and extending onto the calyptra base (Figures 32-34). Valve mantle edge surrounded by a thin hyaline margin (Figure 33, 34). Calyptra straight and eccentric, 22.4-35.5 $\mu \mathrm{m}$ long, positioned at right to slightly oblique angle with the pervalvar axis. Tip of calyptra with 2-3 small teeth and one ligula (Figures 36-38). Terminal seta not observed. Cingulum with several semi-circular open and narrow bands, 7-11(18) in $10 \mu \mathrm{m}$, perforated by round poroids, ca. 8-9 in $1 \mu \mathrm{m}$ (Figure 35). Valvocopula wider than the other bands, with poroids irregularly distributed and smooth margin (Figures 32, 34).

The ultrastructure of $U$. eriensis var. morsa was documented by Torgan \& Becker (1998), based on samples from Patos lagoon, Southern Brazil. The illustrations show the similarities with the material from the State of Paraná, except by the number of teeth in the calyptra apex. We found exemplars with 2 or 3 teeth and one ligula, while Torgan \& Becker (1998) recorded only 2 teeth and the ligula.

Urosolenia eriensis var. morsa differs from the typical variety of species by higher number of girdle bands (Table 4) (Huber-Pestalozzi 1942, Krammer \& Lange-Bertalot 1991, Torgan \& Becker 1998). Urosolenia eriensis var. morsa was found in countries such as Britain, New Zealand, Russia and Brazil (Medvedeva et al. 2009, Tremarin et al. 2009, Guiry \& Guiry 2014).

Few specimens of $U$. eriensis var. morsa were found in Brazilian reservoirs samples, and occur together with $U$. amazonica.

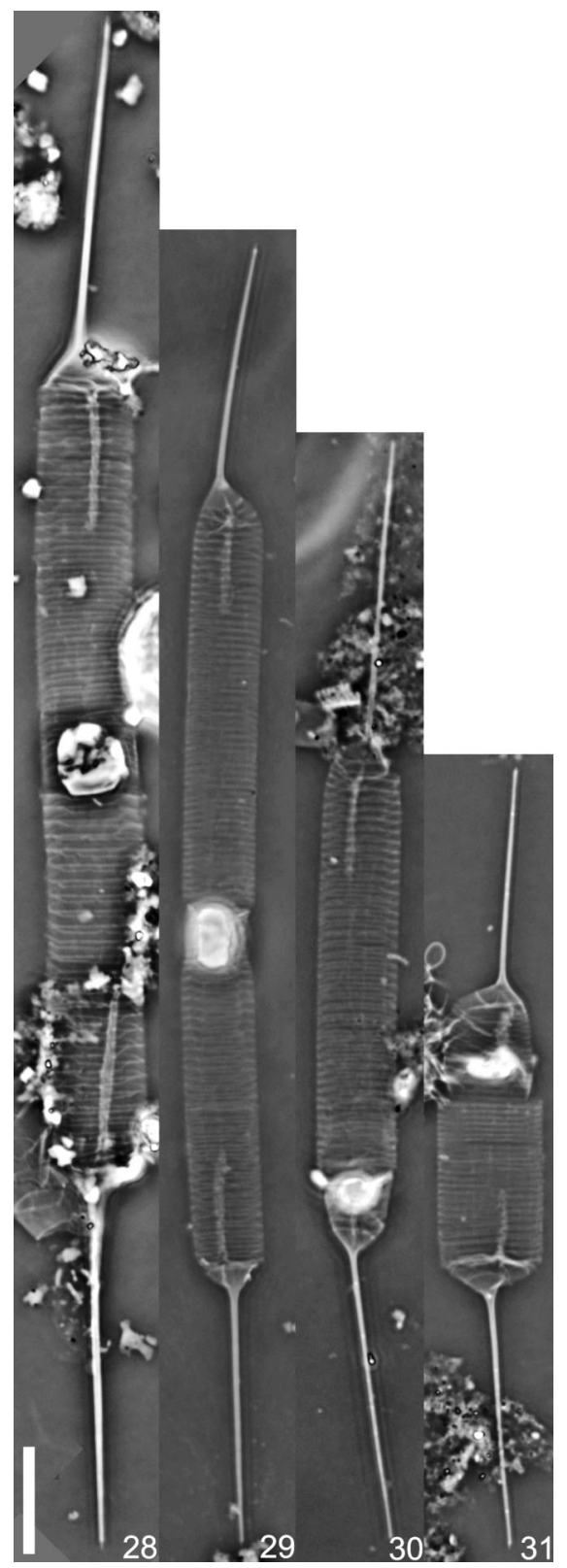

Figures 28-31. Urosolenia eriensis var. morsa, LM. Scale: $10 \mu \mathrm{m}$. 


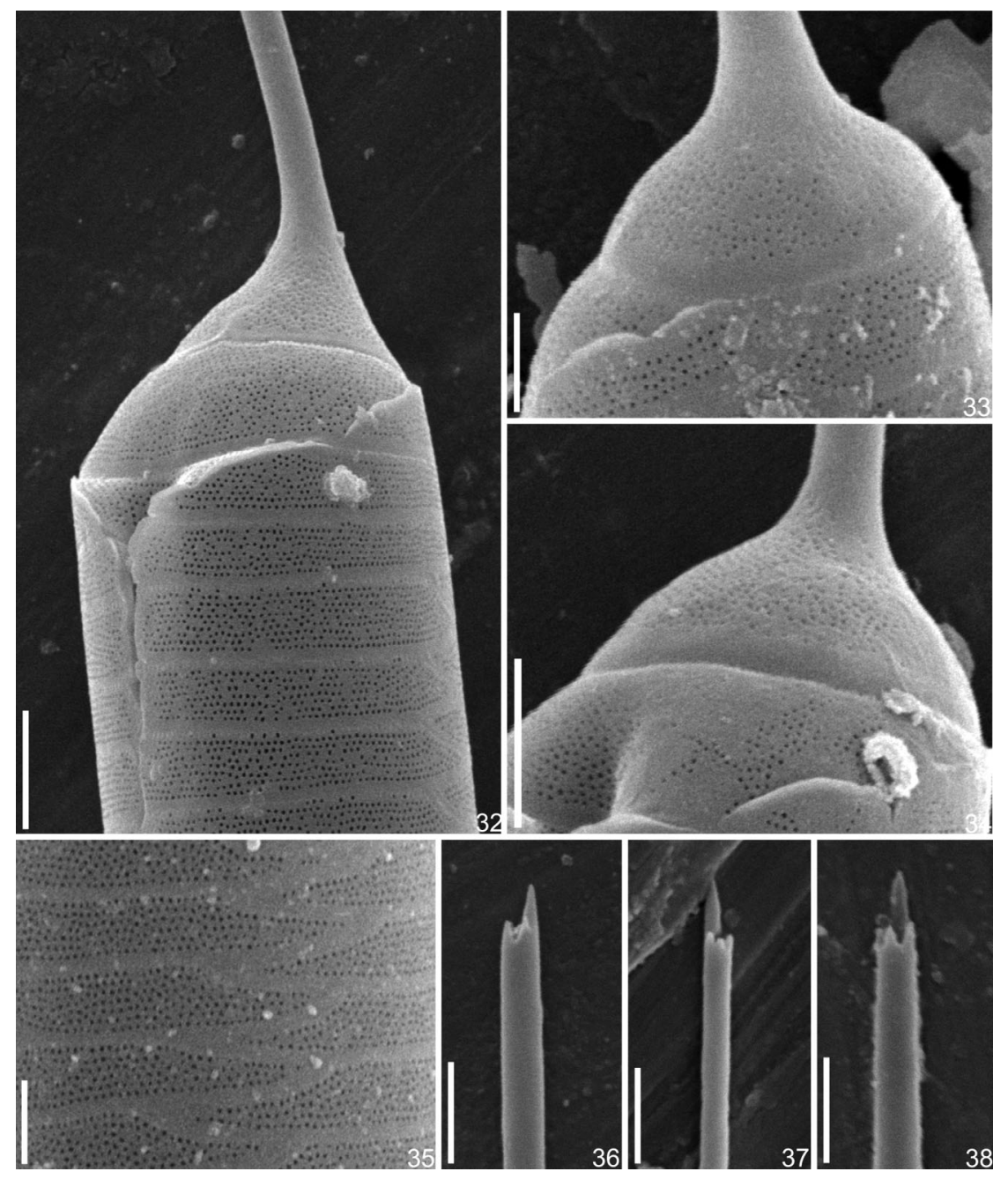

Figures 32-38. Urosolenia eriensis var. morsa, SEM. Fig. 32. External view of frustule showing the insertion site of the calyptra of adjacent cell. Scale: $2 \mu \mathrm{m}$. Figs 33, 34. Aspect of valve in external view and valvocopulae. Scales: $1 \mu \mathrm{m}$ and $2 \mu \mathrm{m}$, respectively. Fig. 35. Detail of girdle bands showing the poroids and imbrication line. Scale: $1 \mu \mathrm{m}$. Figs 36-38. Detail of calyptra teeth. Scales: $1 \mu \mathrm{m}$.

Occurrence in samples (UPCB) - Chaminé reservoir 68845, 68846; Guaricana reservoir 59533; São Jorge reservoir 60526.

Urosolenia longiseta (Zacharias) Edlund \& Stoermer, Journal of Paleolimnology 9(1): 59, pl. 1, figs 5-6, 1993.

Basionym: Rhizosolenia longiseta Zacharias, Forschungsberichte aus der Biologischen Station zu Plön 1: 38; fig. 7, 1893.

Synonym: Urosolenia longiseta (Zacharias) Bukhtiyarova, Algologia 5(4): 417, 1995.

Frustules solitary, cylindrical, straight to slightly curved, 216-273 $\mu \mathrm{m}$ total long, 5.8-8.5 $\mu \mathrm{m}$ width (Figures 39-46). Valve face conical, 2.4-5.4 $\mu \mathrm{m}$ length, ornamented with rounded to elongate areolae, $6-8$ in $1 \mu \mathrm{m}$, arranged in almost linear pattern and extending onto the calyptra base (Figures 47, 48). Valve mantle edge surrounded by a thin hyaline margin (Figure 47). Calyptra straight and central, 64-100 $\mu \mathrm{m}$ long, positioned at right to slightly oblique angle with the pervalvar axis. Tip of calyptra with 3-4 small teeth (Figures 51-55). Terminal seta long (Figure 56). Cingulum with several semi-circular open and large bands, 3-4 in $10 \mu \mathrm{m}$, perforated by elongate poroids, ca. 7-8 in 1 $\mu \mathrm{m}$ (Figures 49, 50).
When proposed Rhizosolenia longiseta, Zacharias (1893) provided only the length of frustule and calyptra (Table 5). Additional, but limited to light microscopy information on the morphology and metric limits was subsequently reported for this species (ex. Krammer \& Lange-Bertalot 1991; HuberPestalozzi 1942). The failure to record the frustules details of $U$. longiseta type material has hampered the comparison of this species with populations from different regions of the world and similar taxa. Attempts to analyze a sample of Rhizosolenia longiseta studied by Zacharias from Schleswig-Holstein, Germany (material number E4347-Hustedt Diatom Collection) failed, because complete frustules were not found. Valves poorly preserved and the lack of integrity of the calyptra did not allow to observe the number and morphology of apical teeth.

Our specimens of Urosolenia longiseta had smaller frustules and shorter calyptra than those described by Zacharias (1893), Huber-Pestalozzi (1942) and Krammer \& Lange-Bertalot (1991) (Table 5). The metric variation recorded was more related to that cited by Zacharias (1898) and Cleve-Euler (1951). 


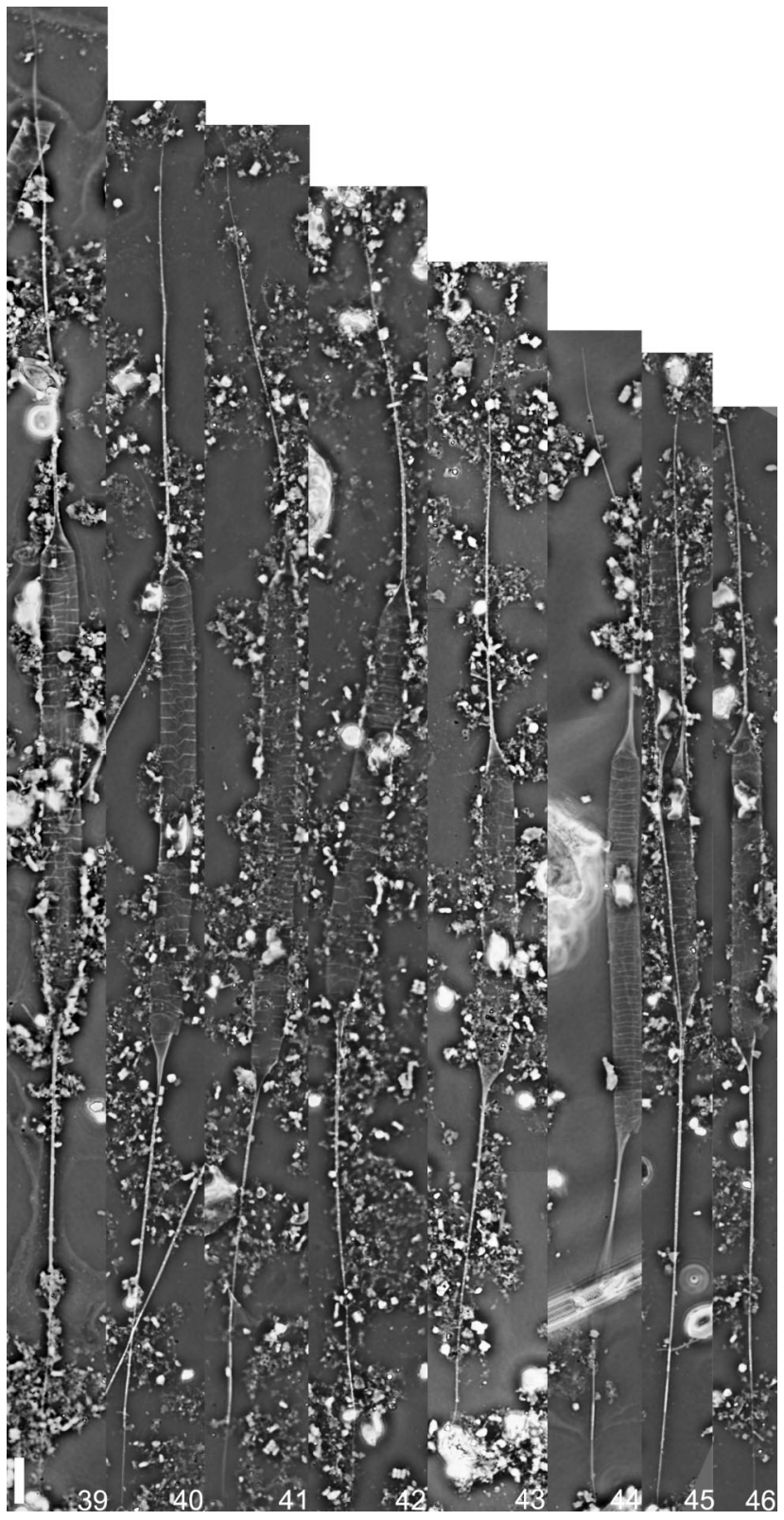

Figures 39-46. Urosolenia longiseta, LM. Scale: $10 \mu \mathrm{m}$.

The ultrastructure of Urosolenia longiseta is still poorly known. Only the morphology of its resting spores was well studied by Edlund \& Stoermer (1993). Thus, the number and morphology of the calyptra teeth and the areolation pattern of the valves and girdle bands of $U$. longiseta are recorded for the first time in this study.

The frustules of $U$. delicatissima Sala, Núñez-Avellaneda \& Vouilloud and $U$. extensa Karthick \& Kociolek are very similar to $U$. longiseta. However, $U$. delicatissima differs mainly by having a bottom, a large labiate-shaped perforation on the valve (Sala et al. 2008). Furthermore, this species may have longer frustules and higher number of bands (Table 5) (Sala et al. 2008, Li et al. 2009). Urosolenia extensa have elongate openings in the valve, greater number of girdle bands, longer valves, higher density of areolae (8-9 in $1 \mu \mathrm{m})$ and shorter calyptra than that $U$. longiseta (Table 5) (Karthick \& Kociolek 2011).
Urosolenia longiseta have a worldwide distribution, recorded in Britain, Ireland, North America, New Zealand, Russia, Germany and Brazil (Krammer \& Lange-Bertalot 1991, Medvedeva et al. 2009, Tremarin et al. 2009, Guiry \& Guiry 2014).

Occurrence in samples (UPCB) - Guaricana reservoir 59533, 60517, 68851, 68875; São Jorge reservoir 59534, 60526, 68852, 68884; Pitangui reservoir 68855, 68879; Fundão reservoir 68864; Foz do Areia reservoir 59530, 60514, 60515, 60516, 68872; Segredo reservoir 59543, 60527, 68861, 68862, 68885; Salto Caxias reservoir 68857; Chaminé reservoir 59527, 60511, 60512, 68845, 68846; Jordão reservoir 59520, 68852; Santa Clara reservoir 68863.

Urosolenia obesa Freire, Tremarin \& Ludwig, Phytotaxa 125(1): 1-9, figs 2-27, 2013.

Frustules solitary, subcylindrical, straight to slightly curved, 27.6-55.2 $\mu \mathrm{m}$ total long, 6.8-14.2 $\mu \mathrm{m}$ width (Figures 57-61). Valve face conical ornamented with rounded to irregular areolae, $8-10$ in $1 \mu \mathrm{m}$, randomly arranged and extending onto the calyptra base (Figure 62). Valve mantle edge surrounded by a thin hyaline margin. Calyptra straight and eccentric, 9.7-15.9 $\mu \mathrm{m}$ long, positioned at right to strongly oblique angle with the pervalvar axis. Calyptra in variable position to the frustules (Figures 57-61). Calyptra ornamented by irregular rib-like structures that extend from base until the median portion of this valve projection (Figure 62). Tip of calyptra with 2 small teeth and a central ligula (Figure 63). Terminal seta not observed. Cingulum with several semi-circular open and narrow bands, 13-16 in $10 \mu \mathrm{m}$, perforated by round poroids, ca. 10-11 in $1 \mu \mathrm{m}$. Coarser rounded pores, varying in size and number, present on both sides of the cingulum (Figure 62). Resting spore subcylindrical, with convex/concave wall, smooth, 5.4-6.5 $\mu \mathrm{m}$ long and 10.1-13.5 $\mu \mathrm{m}$ width (Figure 57).

Urosolenia obesa is a small and delicate taxa recently proposed to South Brazil. Details of frustule morphology and some ecological data of this species were reported by Tremarin et al. (2013) that proposed this taxon. At present, the species was only found in reservoirs of State of Paraná.

Occurrence in samples (UPCB) - Capivari reservoir 59525, 60509, 68843, 68867; Guaricana reservoir 59533, 60517, 68851, 68875; São Jorge reservoir 59523, 60526, 68860, 68884; Pitangui reservoir 59537, 60521, 68855, 68879; Salto do Vau reservoir 59541, 60525, 68859, 68883; Fundão reservoir 68864, 68888; Foz do Areia reservoir 59530, 59531, 59532, 60514, 60515, 60516, 68848, 68849, 68850, 68872, 68873, 68874; Santa Clara reservoir 68863, 68887; Jordão reservoir 59520, 60518, 68852, 68876; Segredo reservoir 59543, 59544, 60527, 60528, 68861, 68862, 68885, 68886; Salto Caxias reservoir 59539, 59540, 60523, 60524, 68857, 68858, 68881, 68882; Mourão reservoir $59536,60520,68854,68878$.

\section{Ecology}

The ecological preferences of Acanthoceras and Urosolenia species are poorly known. Acanthoceras zachariasii was reported as occasionally abundant and ephemeral in several alkaline and eutrophic environments in Europe, North and South America (Rivera 1974, Beaver 1981, Edlund \& Stoermer 1993). In fact, this species was only found at low densities in two studied eutrophic reservoirs in April/2010, (São Jorge reservoir: 37 cells. $\mathrm{mL}^{-1}$ and Pitangui reservoir: 99 cells. $\mathrm{mL}^{-1}$ ), co-occurring with Urosolenia species. Ramberg (1987), when 

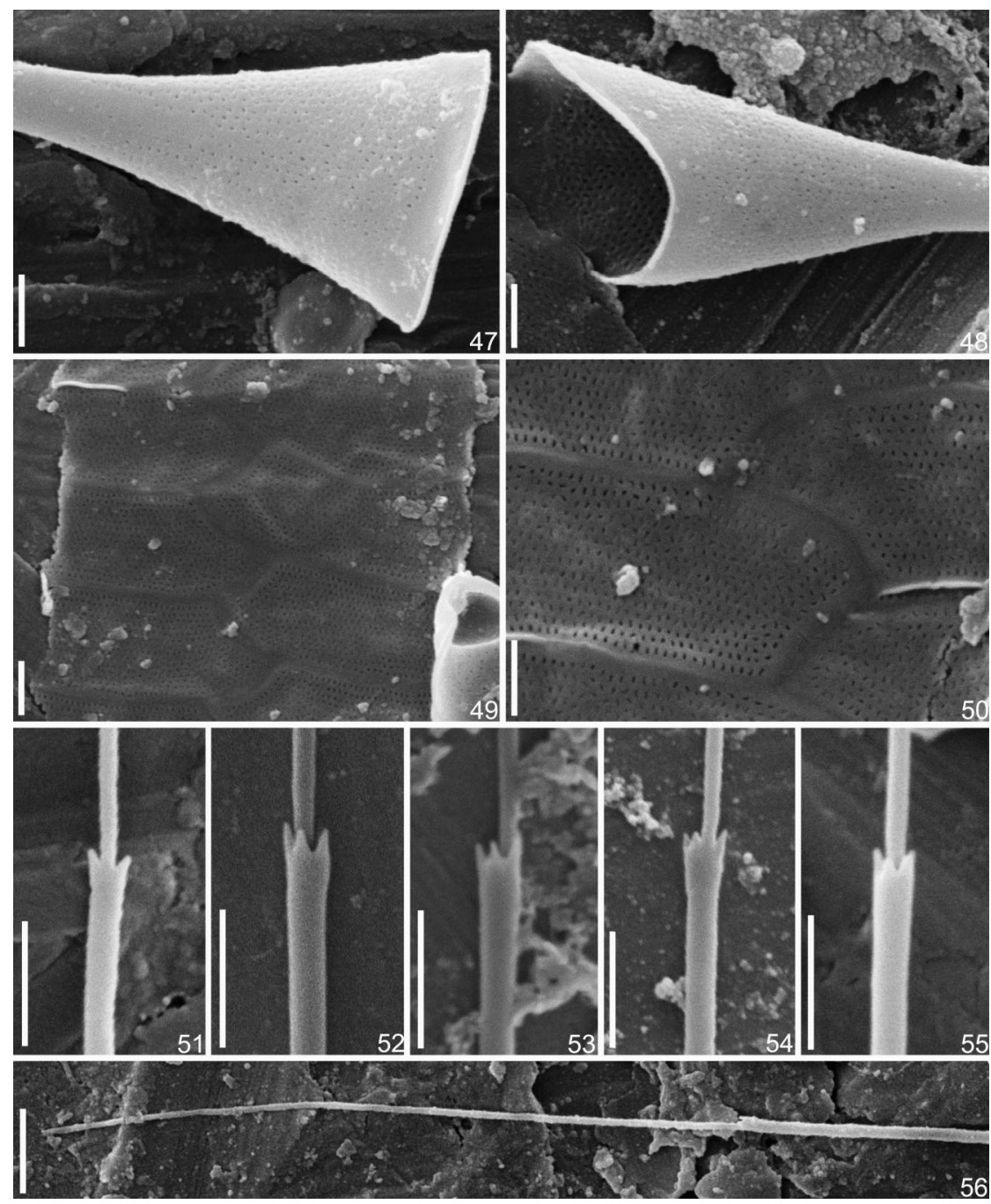

Figures 47-56. Urosolenia longiseta, SEM. Figs 47, 48. External and internal view of valve, respectively. Scales: $1 \mu \mathrm{m}$. Fig. 49. Girdle bands in the median region of frustule. Scale: $1 \mu \mathrm{m}$. Fig. 50. Detail of bands showing the poroids and imbrication line. Scale: $1 \mu \mathrm{m}$. Figs 51-55. Detail of calyptra teeth. Scales: $1 \mu \mathrm{m}$. Fig. 56. Seta in the calyptra. Scale: $1 \mu \mathrm{m}$.

study of phytoplankton of Lake Kariba, observed that $A$. zachariasii occurred in low density in the end of the rainy season and disappeared with the mixing of water column. According to Edlund \& Stoermer (1993), the record of Urosolenia species for several environments with different physical and chemical conditions can be a result of the erroneous determination of taxa. Thus, we emphasize the importance of taxonomic studies to better define the differences between species and their geographical distribution, aiding subsequent ecological studies.

The first two axes from Principal Component Analysis (PCA) exceed expectations from the broken-stick distribution, suggesting these axes are significant and explained $52.52 \%$ of total variance from environmental variables considering 2007 2012. The first axis $(27.66 \%)$ showed positive correlations with reservoir depth $(\mathrm{r}=0.83)$ and to molar $\mathrm{N} / \mathrm{P}(\mathrm{r}=0.83)$ and negative correlations with total phosphorous $(\mathrm{r}=-0.56)$ and $\mathrm{pH}(\mathrm{r}=-0.51)$. Water column turbidity $(\mathrm{r}=0.76)$ and total inorganic nitrogen $(\mathrm{r}=0.68)$ had a significantly positive correlation and water transparency was negatively correlated $(r=-0.60)$ with the second axis $(24.86 \%)$.
In general, the Jordão reservoir was characterized by greater depth, and São Jorge, Pitangui, Guaricana and Chaminé were more alkaline environments. Rio dos Patos and Segredo reservoirs present higher turbidity and nutrient concentrations, but higher transparency characterizes Jordão and Chaminé reservoirs (Figure 64).

Urosolenia amazonica showed occurrence frequency of $78.7 \%$, and despite the density values varied markedly, higher average values were recorded at São Jorge, Pitangui and Chaminé. Spearman rank correlation results revealed positive associations between density and $\mathrm{pH}$, but total inorganic nitrogen, nitrate and reservoir depth were negatively correlated (Table 6). A multiple linear regression model was performed and revealed that total inorganic nitrogen was the main factor influencing $U$. amazonica cellular densities. Along with conductivity, water temperature and molar N/P ratio the model explained $12 \%$ of variance. According to this model, the conductivity was positively associated with $U$. amazonica density, and negatively correlated to total inorganic nitrogen, water temperature and the molar N/P ratio (Table 7). 


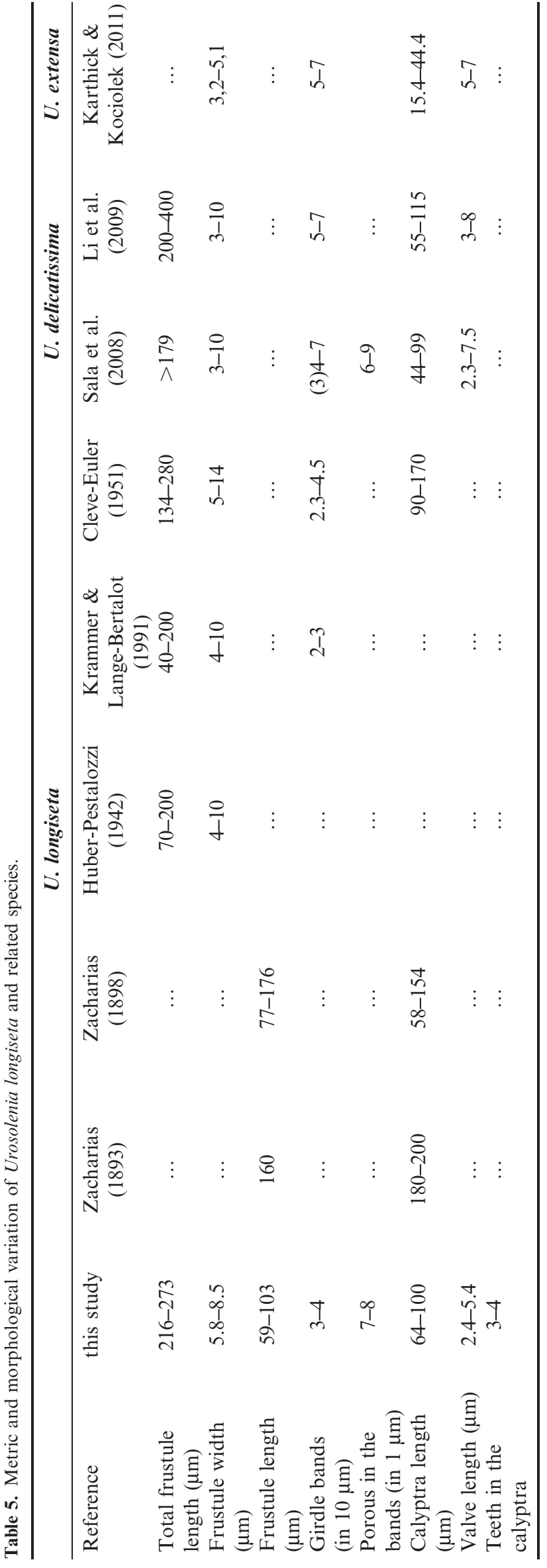

The frequency of $U$. longiseta occurrence was $34.5 \%$. The density values had higher densities in winter season and in the São Jorge and Guaricana reservoirs. The maximum value registered was 486 ind. $\mathrm{mL}^{-1}$ in São Jorge, during the winter of 2008. Urosolenia longiseta density was negatively correlated with depth, molar N/P ratio and water temperature (Table 6). The multiple linear regression model showed that the water temperature and the N/P molar influenced significantly the density of $U$. longiseta in the studied reservoirs. These variables along with depth of the water column, inorganic nitrogen, conductivity and turbidity explained $28 \%$ of $U$. longiseta density between environments and established temporal interval. The water body depth was the only variable positively correlated with the density of this species and all the others were negatively correlated (Table 7).

Frequency occurrence of Urosolenia obesa was 17.8\% during 2007-2012 and the density values were generally lower compared to $U$. amazonica and $U$. longiseta. Higher cell concentrations were achieved at São Jorge and Fundão reservoirs, and greater frequency occurred during fall and winter. Urosolenia obesa was negatively associated with total nitrogen, N/P molar ratio and inorganic total nitrogen (Table 6). Multiple linear regression supported that limnological variables were related to $U$. obesa density. Accordingly, N/P molar ratio was the main variable related to species density variation, along with water temperature and turbidity, the model explained $36 \%$ of data (Table 7 ).

The three Urosolenia species showed distinct frequencies of occurrence and wide density variation among different studied reservoirs, in the period 2007-2012. Statistical analysis showed that such variation was correlated with limnological factors associated with particular characters from each reservoir, influencing the distribution pattern of species. Generally, higher densities of Urosolenia were registered in shallower reservoirs (ex., São Jorge, Pitangui and Guaricana), except for Fundão (38 meters). Residence time (which favors nutrients mixing and resuspension) and hydrodynamics are important determinants of phytoplankton densities in shallow reservoirs (Silva et al. 2005; Reynolds 2006; Lopes et al. 2009; Nogueira et al. 2010).

Higher densities of $U$. amazonica were detected in more alkaline waters and in low inorganic nitrogen and nitrate concentrations, and shallow waters. $U$. longiseta were also recorded in shallower environments (São Jorge and Guaricana), in cooler temperatures. The species is less restricted by phosphorus (lowest N/P ratio). Finally, more elevated densities of $U$. obesa were related to lower concentrations of the nitrogenated forms. Higher densities of $U$. amazonica and $U$. longiseta were recorded by Silva et al. (2005), in two deep reservoirs from Iguaçu River basin (Foz do Areia and Salto Santiago), during lower temperatures and nitrogen forms minor concentrations, besides greater turbulence of the water column. Reported as r-strategists (Reynolds 2006), these centric diatoms thrive in conditions of turbulent water column and low nutrient concentrations, corroborating the general pattern observed in this study.

The performed model selected inorganic nitrogen as the primary determinant of $U$. amazonica density, with a negative coefficient. Urosolenia longiseta showed a negative correlation with temperature and N/P molar ratio, both variables were cited as the main determinants with that species density. N/P molar ratio was selected as the most important variable negatively correlated with $U$. obesa. These results suggest the occurrence of higher densities in periods of warmer tempera- 


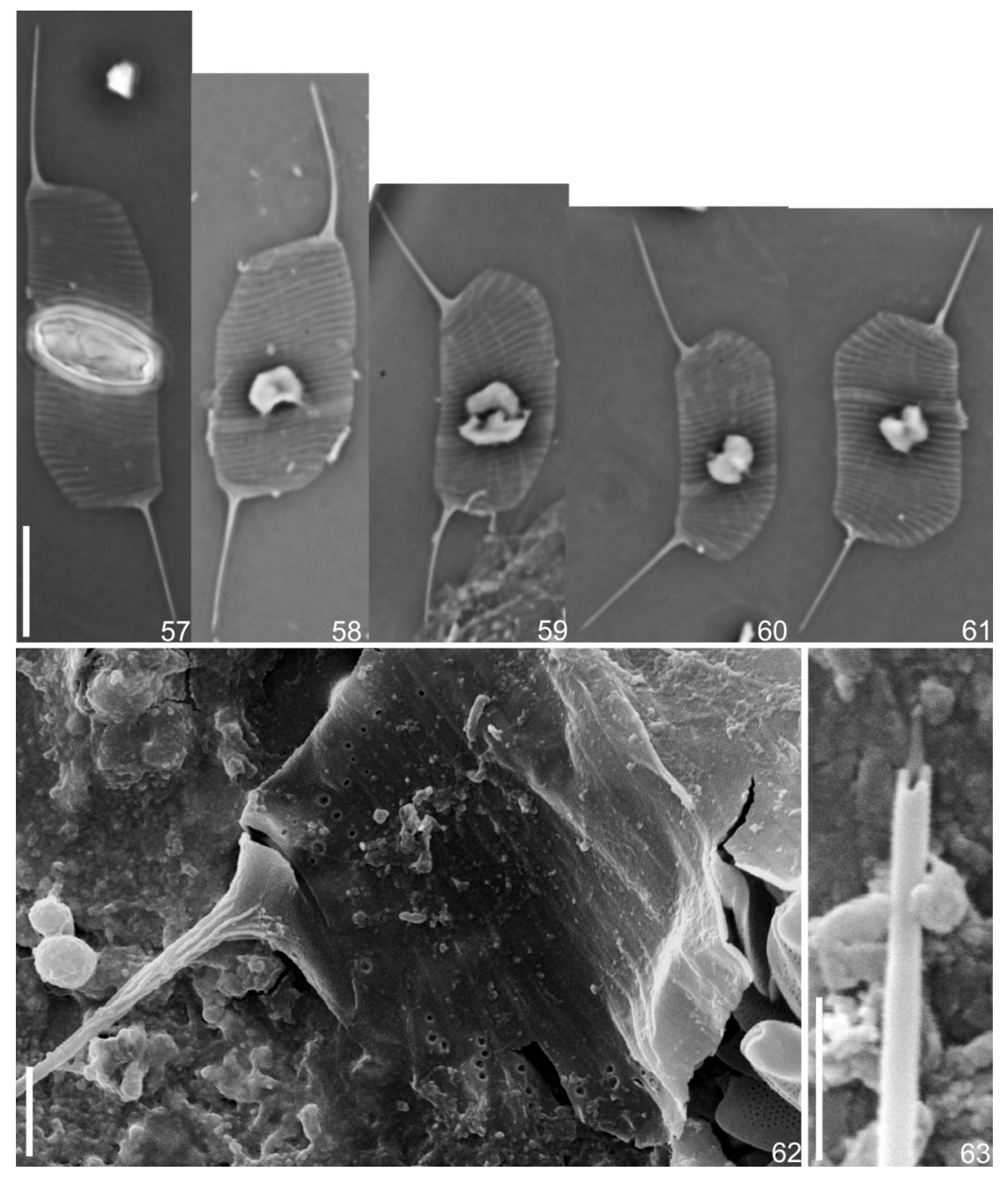

Figures 57-61. Urosolenia obesa, LM. Scale: $10 \mu \mathrm{m}$. Figures 62-63. Urosolenia obesa, SEM. Fig. 62. External view of frustule showing the ornamentation of the valve and girdle bands. Scale: $2 \mu \mathrm{m}$. Fig. 63. Detail of calyptra teeth. Scale: $1 \mu \mathrm{m}$.
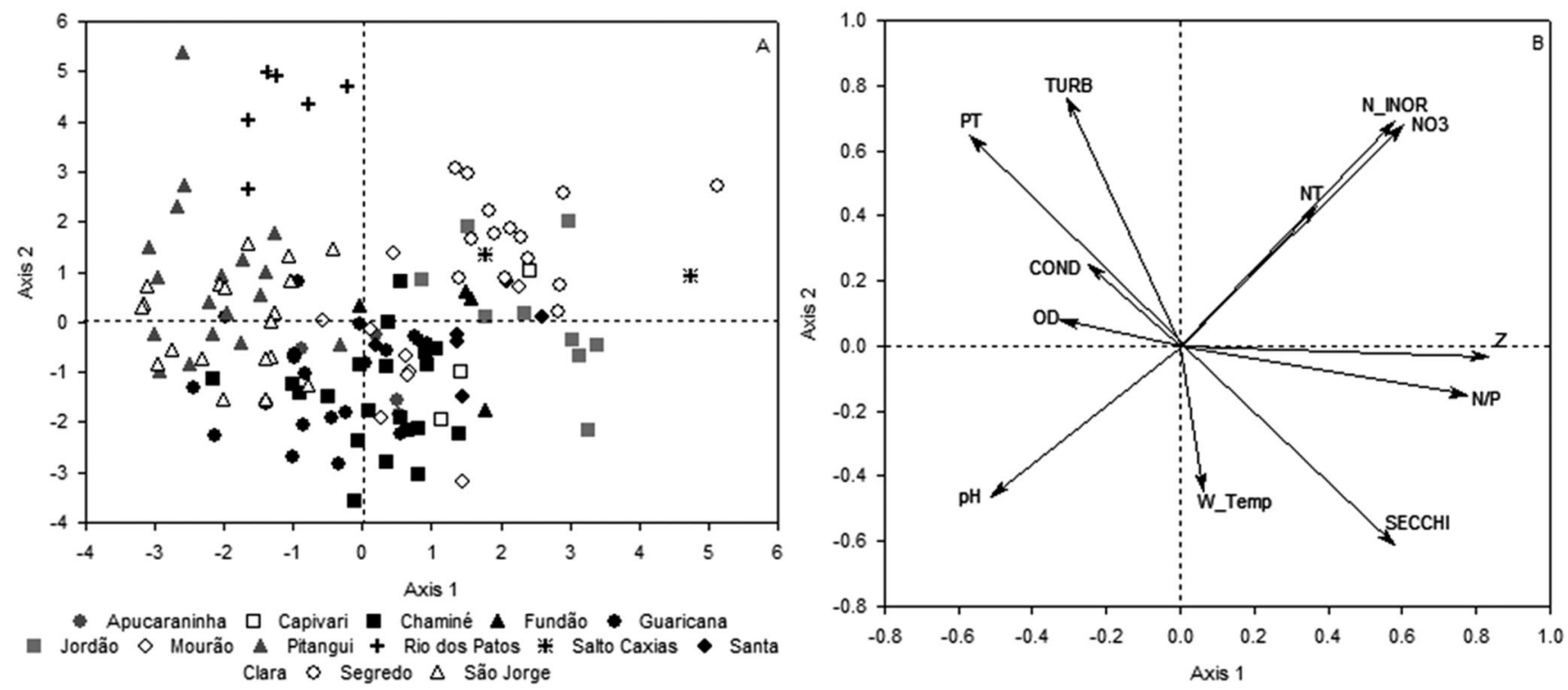

Figure 64. Reservoirs scores (A) derived from principal component analysis and Pearson correlation (B) between the original variables and ordination scores [COND (conductivity); N_INOR (total inorganic nitrogen), NO3 (nitrate), NT (total nitrogen), N/P ratio (N/P molar), DO (dissolved oxygen), PT (total phosphorus), Z (depth reservoir), Secchi (water column transparency); W_temp (water temperature); TURB (turbidity)]. 
Acanthoceras and Urosolenia species in the Brazil

Table 6. Values of Spearman's correlations between species density and environmental variables of the reservoirs. Values in bold $=$ significant correlations.

\begin{tabular}{lccc}
\hline & U. amazonica & U. longiseta & U. obesa \\
\hline $\mathrm{pH}$ & $\mathbf{0 . 2 2 4}$ & 0.179 & 0.144 \\
Log Depth & $\mathbf{- 0 . 2 0 0}$ & $\mathbf{- 0 . 3 4 1}$ & -0.260 \\
Log Conductivity & 0.136 & -0.123 & -0.025 \\
Log Water temperature & -0.081 & $\mathbf{- 0 . 2 9 2}$ & 0.087 \\
Log N/P ratio & -0.145 & $\mathbf{- 0 . 3 0 0}$ & $\mathbf{- 0 . 4 7 5}$ \\
Log Inorganic nitrogen & $\mathbf{- 0 . 2 6 6}$ & -0.148 & $\mathbf{- 0 . 3 1 4}$ \\
Log Nitrate & $\mathbf{- 0 . 2 3 4}$ & -0.165 & -0.268 \\
Log Total nitrogen & -0.093 & -0.225 & $\mathbf{- 0 . 5 0 0}$ \\
Log Turbidity & -0.094 & 0.019 & 0.223 \\
\hline
\end{tabular}

Table 7. Results of a multiple regression analysis of species densities against environmental variables.

\begin{tabular}{|c|c|c|c|c|c|}
\hline & Predictor variables & B & $\mathbf{t}$ & $\mathbf{F}$ & $\mathbf{p}$ \\
\hline \multirow[t]{5}{*}{ U. amazonica } & Intercept & 3.077 & (96) 1.751 & 3.540 & 0.009 \\
\hline & Log Nitrogen inorganic & -2.516 & -2.765 & & 0.006 \\
\hline & Log Conductivity & 0.892 & 1.636 & & 0.105 \\
\hline & Log Water temperature & -1.411 & -1.514 & & 0.133 \\
\hline & Log N/P ratio & -0.263 & -1.127 & & 0.262 \\
\hline \multirow[t]{7}{*}{ U. longiseta } & Intercept & 8.214 & (40) 3.999 & 2.699 & 0.000 \\
\hline & Log Water temperature & -2.977 & -2.591 & & 0.013 \\
\hline & Log N/P ratio & -0.689 & -2.403 & & 0.020 \\
\hline & Log Conductivity & -0.653 & -1.324 & & 0.192 \\
\hline & Log turbidity & -0.334 & -1.142 & & 0.259 \\
\hline & Log Nitrogen inorganic & -1.326 & -0.928 & & 0.358 \\
\hline & Log depth & 0.04 & 0.140 & & 0.888 \\
\hline \multirow[t]{4}{*}{ U. obesa } & Intercept & -0.035 & $(38)-0.018$ & 7.242 & 0.000 \\
\hline & Log N/P ratio & -0.039 & -3.925 & & 0.000 \\
\hline & Log Water temperature & 2.485 & 1.889 & & 0.066 \\
\hline & Log turbidity & 0.366 & 1.030 & & 0.309 \\
\hline
\end{tabular}

tures and low levels of nitrogenated forms (inorganic nitrogen and N/P molar ratio), corroborating the results reported by Flynn (2001) for the phytoplanktonic diatoms community.

As shown, Urosolenia species respond more strongly to local environmental gradients, which are highly influenced by particular local characters (as depth and hydrodynamics of the system). Also, the extent of their ecological amplitude determines the distribution and occurrence pattern of these species in the reservoirs of State of Paraná.

\section{Acknowledgments}

To Coordenação de Aperfeiçoamento de Pessoal de Nível Superior (CAPES) for posdoctoral grant to P. Tremarin, to Fundação Araucária to posdoctoral grant for V. Algarte, and to Conselho Nacional de Desenvolvimento Científico e Tecnológico $(\mathrm{CNPq})$ by the scientific productivity grant for T. Ludwig. To the Instituto de Tecnologia para o Desenvolvimento (LACTEC) and Companhia Paranaense de Energia (COPEL) for providing physical and chemical data and samples for the study; and to the staff of the Electron Microscopy Center of Universidade Federal do Paraná for technical assistance.

\section{References}

APHA - American Public Health Association/AWWA - American Water Works Association/WEF - Water Environment Federation.
1998. Standard methods for the examination of water and wastewater. $20^{\text {th }}$ ed. Washington, DC.

BEAVER, J. 1981. Apparent ecological characteristics of some common freshwater diatoms. Ontario Ministry of the Environment Rpt. 517 pp.

BICUDO, C.E.M. \& MENEZES, M. 2006. Gênero de Algas de águas Continetais do Brasil. Chave para identificação e descrição. Rima, São Paulo. $2^{\mathrm{a}}$ edição.

BRUN, J. 1894. Zwei neue Diatomeen von Ploen. Forschungsb. Biol. Stat. Plön 2:52-56.

CLEVE-EULER, A. 1951. Die diatomeen von Scheweden und Finnland. Kongl. Sven. Vet. Handl. 2(1):1-163.

COMPÈRE, P. 1999. Report of the Committee for Algae: 5. Taxon 48(1):129-132, http://dx.doi.org/10.2307/1224628

EDLUND, M.B. \& STOERMER, E.F. 1993. Resting spores of the freshwater diatoms Acanthoceras and Urosolenia. J. Paleolimnol. 9(1):55-61, http://dx.doi.org/10.1007/BF00680035

EDLUND, M.B. \& WYNNE, M.J. 1996. Proposal to conserve the name Acanthoceras Honigm. (Bacillariophyceae) against Acanthoceras Kutz. (Rhodophyceae). Taxon 45:529-530.

ESKINAZI-LEÇA, E., CUNHA, M.G.G.S., SANTIAGO, M.F., BORGES, G.C.P., LIMA, J.C., SILVA, M.H., LIMA, E.P. \& MENEZES, M. 2012. Bacillariophyceae in Lista de Espécies da Flora do Brasil. Jardim Botânico do Rio de Janeiro. http:// floradobrasil.jbrj.gov.br/2010/FB120853 (Accessed in 11/03/2014).

FERRARIO, M., DAMBORENEA, C. \& SAR, E.A. 1992. Consideraciones sobre Acanthoceras zachariasii (Bacillariophyceae). Darwiniana 31(1-4):357-359.

FLYNN, K.J. 2001. A mechanistic model for describing dynamic multinutrient, light, temperature interactions in phytoplankton. J. Plank. Res. 23(9):977-997, http://dx.doi.org/10.1093/plankt/23.9.977 
GUIRY, M.D. \& GUIRY, G.M. 2014. AlgaeBase. World-wide electronic publication, National University of Ireland, Galway http://www.algaebase.org (Accessed in 01/10/14).

HONIGMANN, H. 1910. Beiträge zur Kenntnis des Süßwasserplanktons. Arch. Hydrobiol. Planktonkunde 5:71-78.

HUBER-PESTALOZZI, G. 1942. Diatomeen. In Das Phytoplankton des Susswassers, Systematik und Biologie (A. Thienimann, ed.), 2:367-549.

HUSTEDT, F. 1930. Bacillariophyta (Diatomeae). Die SüsswasserFlora Mitteleuropas 10:1-466.

JACKSON, D.A. 1993. Stopping rules in principal components analysis: a comparison of heuristical and statistical approaches. Ecology 74:2204-2214, http://dx.doi.org/10.2307/1939574

KARTHICK, B. \& KOCIOLEK, J.P. 2011. Four new centric diatoms (Bacillariophyceae) from the Western Ghats, South India. Phytotaxa 22:25-40.

KRAMMER, K. \& LANGE-BERTALOT, H. 1991. Freshwater flora of Central Europe. Bacillariophyceae: Centrales, Fragilariaceae, Eunotiaceae. In Süsswasseflora von Mitteleuropa. (H. Ettl, I. Gerloff, H. Heyning \& D. Mollenhauer, eds).Stuttgart: G. Fischer, 576p.

KÜTZING, F. 1842. Ueber Ceramium Ag. Linnaea 15:727-746.

LEGENDRE, P. \& LEGENDRE, L. 1998. Numerical Ecology. $2^{\text {nd }}$ English ed. Amsterdam: Elsevier.

LI, Y., CEN, J.Y., QI, Y.Z. \& LÜ, S.H. 2009. Morphological features observations of Urosolenia in Chinese freshwaters. Acta Hydrobiol. Sin. 33(3):566-570, http://dx.doi.org/10.3724/SP.J.1035.2009.00566

LOPES, M.R.M, FERRAGUT, C. \& BICUDO, C.E.M. 2009. Phytoplankton diversity and strategies in regard to physical disturbances in a shallow, oligotrophic, tropical reservoir in Southeast Brazil. Limnetica 28(1):159-174.

LUND, J.W.G., KIPLING, C., LE CREN, E.D., 1958. The inverted microscope method of estimating algal numbers and the statistical basis of estimations by counting. Hydrobiologia 11:143-170, http:// dx.doi.org/10.1007/BF00007865

McCUNE, B. \& MEFFORD, M.J. 1999. PC-ORD. Multivariate analysis of Ecological Data, Version 4.0 for Windows.

MEDVEDEVA, L.A., NIKULINA, T.V. \& GENKAL, S.I. 2009. Centric diatoms (Coscinodiscophyceae) of fresh and brackish water bodies of the southern part of the Russian Far East. Oceanological and Hydrobiological Studies 38(2):139-164, http://dx.doi.org/ 10.2478/v10009-009-0018-4

MELO, S., HUSZAR, V.L.M., ROLAND, F., ESTEVES, F.A. \& BOZELLI, R.L. 2004. Phytoplankton diel variation and vertical distribution in two Amazonian flood-plain lakes (Batata Lake and Mussurá Lake, Pará-Brasil) with different mixing regimes. Amazoniana 18(1/2):1-10.

MORALES, E.A. 2005. Observations of the morphology of some known and new fragilarioid diatoms (Bacillariophyceae) from Rivers in the USA. Phycol. Res. 53:113-133, http://dx.doi.org/ 10.1111/j.1440-1835.2005.tb00363.x

NOGUEIRA，M.G., FERRAREZE，M., MOREIRA，M.L. \& GOUVÊA, R.M. 2010. Phytoplankton assemblages in a reservoir cascade of a large tropical - subtropical river (SE, Brazil). Braz. J. Biol. 70(3):781-793, http://dx.doi.org/10.1590/S1519-6984 2010000400009

RAMBERG, L. 1987. Phytoplankton succession in the Sanyati basin, Lake Kariba. Hydrobiol. 153:193-202, http://dx.doi.org/10.1007/ BF00007206

RAUPP, S.V., TORGAN, L.C. \& MELO, S. 2009. Planktonic diatom composition and abundance in the Amazonian floodplain Cutiuaú Lake are driven by the flood pulse. Acta Limnol. Brasil. 21(2):227234.

REYNOLDS, C.S. 2006. The ecology of phytoplankton.Cambridge: Cambridge University Press,
REYNOLDS, C.C., HUZSAR, V., KRUK, C., NASELLI-FLORES, L. \& MELO, S. 2002. Towards a functional classification of the freshwater phytoplankton. Journal of Plankton Research 24(5):417-428.

RIBEIRO, L.H., KISHI, R., BRASSAC, N.M. \& LUDWIGT.A.V. 2006. Metodologia aplicada para avaliação da qualidade das águas superficiais em reservatórios da COPEL e corpos hídricos relacionados.Curitiba: LACTEC. 18p.

RIVERA, P. 1974. Diatomeas de la Laguna Verde del Parque Hualpen, Chile. I. Interesantes representantes del genero Atteya (West, 1860). Boletín Sociedad de Biología de Concepción 47:87-91.

ROTT, E., KLING, H. \& McGREGOR, G. 2006. Studies on the diatom Urosolenia Round \& Crawford (Rhizosoleniophycideae) Part 1. New and re-classified species from subtropical and tropical freshwaters. Diatom Res. 21:105-124.

ROUND, F.E., CRAWFORD, R.M. \& MANN, D.G. 1990. The diatoms: biology and morphology of the genera.Cambridge University Press, Cambridge.

SALA, S.E., NÚÑEZ-AVELLANEDA, M. \& VOUILLOUD, A.A. 2008. Ultrastructure of the frustule Urosolenia species from the Colombian and Peruvian Amazon: $U$. delicatissima spec. nov., $U$. amazonica spec. nov. and $U$. braunii (Hustedt) root e Kling. Diatom Res. 23(1):159-169, http://dx.doi.org/10.1080/0269249X.2008. 9705744

SHIRATA, M.T. \& VALENTE-MOREIRA, I.M. 1987. Ocorrência das diatomáceas Attheya zachariasi e Surirella stalagma no lago Parque São Lourenço, Curitiba, PR, Brasil. Acta Biol. Par. 16(1-4):87-92.

SILVA, C.A., TRAINT, S. \& RODRIGUES, L.C. 2005. Phytoplankton assemblages in a Brazilian subtropical cascading reservoir system. Hydrobiologia 537:99-109, http:// dx.doi.org/10.1007/s10750-004-2552-0

SILVA, W.J., NOGUEIRA, I.S. \& SOUZA, M.G.M. 2011. Catálogo de diatomáceas da região Centro-Oeste brasileira. Iheringia, Serie Botânica, 66(1):1-32.

SOKAL, R.R. \& ROHLF, F.J. 1981. Biometry. Second Edition. New York: W. H. Freeman.

STATSOFT, INC. 2005. Statistica (data analysis software system). Version 7.1. http://www.statsoft.com (Accessed in 12/07/2014).

TORGAN, L.C. \& BECKER, V. 1998. The transfer of Rhizosolenia eriensis H.L. Smith var. morsa W. West et G.S. West to Urosolenia (Bacillariophyceae). Iheringia, Série Botânica, 50:89-97.

TORGAN, C.T., BECKER, V. \& PRATES, H.M. 1999. Checklist das diatomáceas (Bacillariophyta) de ambientes de águas continentais e costeiros do Estado do Rio Grande do Sul, Brasil. Iheringia, Série Botânica, 52:89-144.

TREMARIN, P.I., FREIRE, E.G. \& LUDWIG, T.A.V. 2013. Ultrastructure and distribution of Urosolenia obesa sp. nov. (Rhizosoleniaceae, Diatomeae) in reservoirs from Southern Brazil. Phytotaxa 125(1):1-9.

TREMARIN, P.I., FREIRE, E.G., BERTOLLI, L.M. \& LUDWIG, T.A.V. 2009. Catálogo das diatomáceas (Ochrophyta-Diatomeae) continentais do estado do Paraná. Iheringia, Série Botânica, 64(2):79-107.

UHELINGER, V. 1964. Étude statisque des méthodes de dénobrement planctonique. Journal of Archaeological Science, 17:121-123.

UTERMÖHL, H. 1958. Zur vervollkommung der quantitativen phytoplankton methodik. Mitteilung Internationale Vereinigung für Theoretische und Amgewandte Limnologie 9:1-38.

ZACHARIAS, O. 1893. Faunistische und biologische Beoachtungen am Grosser Ploner See. Forschungsber. Biol. Stat. PlönBerlim, p. 1-52.

ZACHARIAS, O. 1898. Mitteilungen über Atheya zachariasi Brun und Rhizosolenia longiseta Zach. Biologisches Centralblatt 18(5): $161-166$.

ZAR, J.H. 2010. Biostatistical analysis. New Jersey: Prentice Hall. 